\title{
Printsess herneteral: traditsioon ja tõlgendus
}

Christine Shojaei Kawan

Printsess herneteral on üks kõige tuntumaid muinasjutte. Saksa keeles kasutatakse selle jutuliigi kohta küll terminit Märchen, kuid lugu ei saa siiski nimetada rahva- ega imemuinasjutuks. Variante on sellel vähe. Antud jututüübi (AT 704 (Printsess herneteral); Aarne-Thompson 1961) levinuim esindaja on mõistagi H. C. Anderseni Prindsessen paa Erten $^{1}$ (eesti k Printsess herneteral).

Elas kord prints, kes tahtis endale printsessi naiseks saada, aga see pidi tõeline printsess olema. Ta rändas siis kogu maailma läbi, et niisugust leida, aga igal pool oli midagi takistuseks ees - printsesse oli küllalt, aga kas nad ikka tõelised printsessid on, selle kohta ei saanud ta kunagi täit selgust, sest alati oli midagi, mis ei olnud nii, nagu oleks pidanud olema. Nii tuli ta siis koju tagasi ja oli väga kurb, sest ta tahtis nii kangesti tõelist printsessi naiseks saada.

Ühel õhtul oli väga halb ilm: lõi välku ja müristas, vihma valas nagu oavarrest, nii et päris jube kohe! Korraga koputati linna väravale, ja vana kuningas läks avama.

Värava taga oli üks printsess. Aga kuidas ta, jumal hoidku, vihma ja halva ilma tõttu välja nägi! Tema juustest ja riietest nirises vett alla, seda voolas tema kinganinadest sisse ja kandadest välja, ja ise ta veel ütles, et on tõeline printsess.

"Noh, küll me seda teada saame!" mõtles vana kuninganna, kuid ei ütelnud mitte midagi, läks magamistuppa, võttis kõik voodiriided ära ja pani voodi põhja herne, tõi seejärel kakskümmend madratsit, asetas need herne peale, ja siis kakskümmend hahasulgedega täidetud magamiskotti veel madratsitele otsa.

Seal pidi nüüd printsess öösel magama.

Hommikul küsiti temalt, kuidas ta magas.

“Oh, hirmus halvasti!” ütles printsess. "Ö̈̈ läbi ei saanud ma peaaegu sõba silmale! Jumal teab, mis seal voodis oli. Ma

http://haldjas.folklore.ee/tagused/nr24/herneteral.pdf 


\section{Christine Shojaei Kawan}

lamasin mingi kõva asja peal, nii et terve keha on mul siniseid plekke täis! Päris jube kohe!”

Sellest, et ta läbi kahekümne madratsi ja kahekümne hahasulgedega täidetud magamiskoti hernest oli tundnud, nähti, et ta on tõeline printsess. Sest mitte keegi peale tõelise printsessi ei või nii ôrna nahaga olla.

Prints võttis ta siis naiseks, sest nü̈̈d teadis ta, et tal on tõeline printsess, ja hernes paigutati muuseumi, kus ta on veel praegugi näha, kui keegi ei ole teda ära viinud.

Vaadake, see on tõestisündinud lugu! (Andersen 1987:64). ${ }^{2}$

Printsess herneteral on üks varasemaid Anderseni muinasjutte, mis ilmus 1835. aastal koos kolme muu jutuga (Eventyr 1963: 41 jj; Eventyr 1990b: 25; Holbek 1977: 491), ja kirjanik väidab end mäletavat seda lugu lapsepõlvest (Eventyr 1963: 19 jj; Eventyr 1990a: 4). Kuna aga taani rahvatraditsioonis pole leitud ühtegi selle loo varianti ega ka ühtegi sarnast lugu, on tema väidet peetud küsitavaks (Christensen 1906: 168 jj; Holbek 1990: 166; Penzer 1923: 290). On ka oletatud, et H. C. Anderseni jutt on idamaist päritolu (vrd Marzolph 2002a: 368; Holbek 1977: 491), kuid seegi pole päris õige, sest analoogset idamaist lugu pole olemas.

Täpsemalt öeldes põhineb Printsess herneteral kolmel eraldisel omavahel läbipõimunud motiivil: ülitundlikkuse (Thompson 1956; vt ka Bolte \& Polívka 1918: 238 jj), ${ }^{3}$ erakordse taibukuse ja pruudi proovilepaneku motiivil. Neist kaks esimest on tõenäoliselt idamaist päritolu ja juba väga vanad.

\section{I. Ülitundlikud naised}

Ülitundlikkusel on üldiselt kerge negatiivne varjund ja seda omistatakse peamiselt naistele, kes näivad seeläbi naeruväärsete, kergesti haavatavate ja seega kasututena, sageli ka moraalselt allakäinutena. Antud motiivi kontseptsiooni leiab 9.-13. sajandi araabia ja pärsia luuletajate ja ajaloolaste (Tabarī, Mascūdī, Tacālibī jt) sõja, armastuse ja reetmise teemalistest jutustustest, mida on üksikasjalikult uurinud taani orientalist Arthur Christensen (Christensen 1936: 241-250). Kui loo kangelanna Nadīra või Mālika (Mulalka) isa linn on sattunud vaenlase piiramisrõngasse, armub tütarlaps vaenlaste kuningasse Šāhpuhri või Ardašēri ja saab talt lubaduse temaga abielluda. Seepeale aitab tütarlaps võoorkuningal linna vallutada, põhjustades 
nii oma isa surma. Enamikus versioonides märkab kuningas ühel ööl, et naine on verine, sest mirdilehed on kriimustanud tema nahka. Motiivi ülesanne on hoopis teistsugune kui jutus Printsess herneteral: siin peab see meenutama kangelanna abikaasale, et naine reetis omaenda isa - isa, kes oli hellitanud teda luuüdi, munakollase, koore, mee ja veiniga, millega kuningas seletab ka tema harukordset tundlikkust. Alles nüüd saab kuningas aru, et naine on tänamatu ja kõlvatu, seega ka ohtlik, ning tapab ta.

A. Christensen keskendus peamiselt antud loo neljateistkümne variandi läbivate joonte uurimisele ja nendega seotud narratiivimotiivide võrdlemisele teiste analoogsetega, kusjuures erilise tähelepanu all oli Printsess herneteral. Ta ei pööranud erilist tähelepanu jutu loogikale ${ }^{4}$ ega naistevihkamise aspektile: oma uurimuse lõppkommentaaris kirjeldab ta juttu kui tüüpilist muistsete iraanlaste halastamatu kohtumõistmise väljendust, samas pole seal ei halastust ega ka õiglust kohtumõistmisel - headus on lihtsalt omistatud meessoole ja kurjus naissoole. Kuningas unustab, et ka ta ise oli osaline kuriteos ja oleks võinud naise isa elu säästa. ${ }^{5}$ Kangelanna tundlikkust ja õrnust ei peeta millekski loomuomaseks, vaid erilise kohtlemise tagajärjeks, mis pole tekkinud mitte ema või amme hoole, vaid isa ülehoolitsuse tulemusena. Sel hetkel, kui kuningas saab teada oma naise tavatust ülitundlikkusest, lahtub ka armuloitsu mõju ${ }^{6}$ ja mehele muutub asemel veritsev naine vastumeelseks. Sedalaadi lugu, kus on läbipõimunud kõlvatus ja ilu, on omamoodi heaks vabanduseks, et vabaneda soovimatust kaasast.

Hilisemad ülitundlikkuse motiivi sisaldavad lood on humoorikad või poolhumoorikad: seal naeruvääristatakse kõrgest soost inimeste (eelkõige just kõrgest soost naisterahvaste - kummalisel kombel peetakse meessoost tegelasi, kes peaksid olema sama siniverelised, täiesti normaalseteks) nõrkust ja kombelõtvust.

Ühes katalaani jutus püüab kuningas asjatult oma ülitundlikke tütreid mehele panna. Lugu algab järgmiselt:

Elas kord kuningas Butxaques. Tal oli kolm tütart, kes olid nii [---] ornad, et jäid küünlavalgusest pimedaks, hingamise häälest kurdiks ja neil läks leivalõhna peale süda pahaks (Amades 1950: nr 393). 


\section{Christine Shojaei Kawan}

Isa on endast väljas: miks on ta tütred nii õrnakesed? Miks ei või nad olla nagu teised? Kohtudes peigmehekandidaatidega haavab esimese tütre pead roosileheke, teine tütar nikastab padjahunnikule istudes puusa, kolmas külmetub, kui sääsk kahekordsete klaasidega aknast mööda lendab. Ja kedagi neist ei saa terveks ravida. Teised katalaani lood jutustavad samalaadsetest hädadest. ${ }^{7}$

Katalaani juttude roosilehemotiiv meenutab anekdooti Sybarises elanud Smindyridesest (Mindyridesest), kes jäänud haigeks vähimastki viitest tööle ja tihti äganud, kui kurnav on roosilehtedel magamine (Seneca De ira 2, 25, $2(41-49 \mathrm{pKr})$; Claudius Aelianus Variae historiae 9, 24 (2.-3. saj.)). Suur-Kreeka koloonia Sybaris, mille Krotoni väed 510. aastal eKr hävitasid, oli tuntud oma elanike jõukuse ja ekstravagantsuse, eriti aga nende kulinaarsete saavutuste poolest. Herodotose järgi $(6,127)$ oli Smindyrides kõige suurejoonelisem neist kosilastest, kes saabusid Kreekasse, et võita enesele Sikyoni türanni Kleisthenese tütart (oletatavalt umbes aastal 572 a eKr). Ka on teada, et kartes, et emamaa [s.t Kreeka toim] ei vasta tema vajadustele, tõi ta endaga kaasa tuhat kaaskondlast, teiste hulgas kalamehi, kokkasid ja linnupü̈̈djaid (Davidson 1998: I ptk; vt ka Hill \& Wilkins 1996). ${ }^{8}$ Sybarise linna ja selle elanikke tunti pigem luksusearmastuse, naudinguiha ja gurmaanluse $^{9}$ kui dekadentliku ülitundlikkuse poolest. Seneca püüab Smindyridese anekdoodi kaudu kritiseerida keha ja vaimu mandumist ihasid nautleva eluviisi juures, mis teeb mehed nõrgaks ja ebamehelikuks - seega peab Seneca Smindyridese ülitundlikkust pelgalt olukorrast tulenevaks.

Roosilehe-voodi anekdoot Smindyridesest paistab olevat ainus seda tüüpi lugu, mis ei kõnele naistest, samuti pole siin erilist rõhku pandud narratiivsusele. Lugu saab vaid kaudselt olla seotud katalaani narratiividega, millel on suurem sarnasus kogumikus Vetāla kakskümmend viis juttu (Vetālapañcavimśatikā; vt Mäll \& Masing 1969) leiduva jutustusega. See india lugude kogumik on olemas mitmes sanskriti, aga ka hindi, bengali, marathi, tamili, telugu ja kannada versioonis. Varaseim kriitiliselt revideeritud tekst pärineb 10. sajandist, ehkki kogumik arvatakse olevat pärit veelgi varasemast ajast. ${ }^{10}$ Selles on juttu kolmest kuningannast, kes olid nii õrnad, et üks neist tegi endale lootoseõiega viga, teine sai kuukiirtelt kõrvetada, ja kolmandale tekkisid kätele sinikad (või sai ta peavalu) pelgalt uhmrinuia tampimist kuuldes (Tawney 1884: 281-283 (ptk 85, nr 11)'11. Oma kirjutises, mis käsitleb H. C. Anderseni juttude 
päritolu (Christensen 1906: $172 \mathrm{jj}$ ), selgitab Georg Christensen, et india jutus kujutatakse daamide õrnust erakordse võlu väljendusena ning Vetāla ${ }^{12}$ küsimus (mille ka leiame ühest katalaani jutust) Ütle mulle, kuningas, kes kolmest kuningannast oli kõige õrnem? tähendab sisuliselt otsesõnu: Kes on kõige kaunim? (Alcover 1953: 49 jj). Kui see tõlgendus on õige, on India kuningannad kuninga hinnaline omand, ja seega erineb india lugu suuresti euroopa lugudest, mis enamasti naeruvääristavad naiselikku nõrkust ja dekadentlikkust, ning ka araabia-pärsia traditsioonist, mille järgi tavatu ülitundlikkus aitab ära tunda kõlvatust ja võimalikku ohtlikkust.

Georg Christensen usub, et tundlikkus väärtuskriteeriumina on just see liin, mille hindud on lisanud roosileheanekdoodile Smindyridesest. Christensen - nagu ka klassik Erwin Rohde (Schick 1934: 144) - peab just roosileheanekdooti igasuguste ülitundlikkuse motiivide allikaks, seega on sealt pärit ka jutu Printsess herneteral algmed (Christensen 1906: 173). Arthur Christensen seevastu oletab motiivi polügeneetilist päritolu (Christensen 1936: 251).

Kahtlemata on kasutu spekuleerida jutu lõpliku päritolu teemadel, ${ }^{13}$ ent narratiivsest aspektist on 20 . sajandi katalaani variandid palju lähedasemad muistsele india jutule kui Smindyridese-anekdoodile või Christenseni kirjeldatud araabia-pärsia pärimusele printsessist mirdilehel. Kuidas on aga india narratiiv sattunud katalaani traditsiooni? Võib arvata, et kirjanduse kaudu, kuid kumbki kahest euroopa kirjanduslikust variandist, mis asuvad kusagil vahepeal, pole piisavalt sarnane, et seda pidada otseseks allikaks.

Antoine Le Métel d'Ouville'i prantsuse pilkelugude kogumikust L'Élite des contes, mis ilmus esimest korda aastal 1643 (Le Métel d'Ouville 1883; vrd Graeber 2000), leiame loo neljast tundlikkuses võistlevast naisest (Le Métel d'Ouville 1883: 149-151). Lugu sisaldab kaht iseloomulikku motiivi, üks neist on üsna ebatavaline ja teine skatoloogiline motiiv loo lõpus. ${ }^{14}$ Kuigi autor räägib rumalavõitu naisterahvastest ja kuigi ka tundlikkusvõistlus on lihtsalt sohimäng (mis viitaks justkui naiselikule silmakirjalikkusele), ei ole põhjust seda juttu tõsiselt võtta - see on vaid lõbus lugemispala, nagu katalaani loodki. Peale selle on haruldane, et loos puuduvad meestegelased kui armastuse objektid või võistlusele õhutajad ning kohtunik, kelle naised appi paluvad, satub sellisesse segadusse, et ei suuda otsust langetada. $^{15}$

Teine euroopa kirjalik tunnistus naiselikust ülitundlikkusest on Christoforo Armeno kuulsas teoses Peregrinaggio di tre giovani fig- 


\section{Christine Shojaei Kawan}

liuoli del Re de Serendippo (1557), mis on üheks oluliseks idamaise, eriti pärsia narratiivi vahendajaks ning levinud laialt tänu väljaannetele ja tõlgetele (vrd Ranke \& Schenda 1979). Antud lugu erineb katalaani lugudest ja prantsuse pilast nii sisu kui ka vaimukuse poolest. Nagu pärsia pärimuses Šāhpuhri Ardašāri reetliku naise puhul, nii jõutakse ka siin pea kogu naissoo hukkamõistuni: naistesse eelarvamusega suhtuvat printsi sunnitakse abielluma, kusjuures kolm neljast võimalikust pruudist osutuvad teesklejateks ja pahelisteks. Esimene teeskleb, et roosilehed teevad talle valu, teisele teeb haiget kuninga karusnahk, kolmandat solvavat isaste kalade nägemine. Samal ajal on kõik kolm armusuhetes madalat päritolu kallimatega ja lasevad endaga vägivaldselt käituda (see detail lubab oletada sadomasohhistlikke kalduvusi ja varjatut sõnumit, et naistele on vaja korralikku keretäit) (Fischer \& Bolte 1895: 116132).

Selle jutu raamistik on laenatud Nezāmi (1141-1203) teosest Haft peikar (Haft Peykar; eesti k Seitse kaunitari (Marzolph 1999: 1435 jj)), aga jutt ise lähtub Papagoiraamatu traditsioonist (vrd Marzolph 2002b). Huvitaval kombel esineb analoogne variant (kolme naisega) pärsia (ja kurdi) rahvakirjanduses, selleks on Čehel Tuti (Nelikümmend papagoid), mis on dateeritud alles 19. sajandi esimesse poolde) (Marzolph 1979: 31 jj, 93 jj).

Lugu on järjekordne mugandus varasematest klassikalistest india, pärsia ja türgi Papagoiraamatu (Schmidt 1899: 31-35 (nr 5), 63-65 (nr 17); Schmidt 1897: 96-98 (nr 5), 101-103 (nr 9)) ${ }^{16}$ tekstidest. Seal on juttu kuninga kaasast, kes on silmakirjalikkuse ja pahelisuse võrdkuju ning kellest võtab eeskuju täpselt samavõrra paheline teenrinaine. Tüüpiliseks motiiviks selles pärimuses on valehäbi isast kala nähes, mis on nii liialdatult naeruväärne, et ajab naerma ka lauale toodud küpsetatud, või siis surnud kalad. ${ }^{17}$ Sellistes lugudes leidub tihti ka sadomasohhistlikku alatooni. Lisaks on tähelepanuväärne, et antud lugude mõlemad naistegelased on kui personifitseeritud pahed, samal ajal kui Čehel Tutis ja Peregrinaggios osutub vähemalt üks kolmest (neljast) naisest täiuslikuks.

Teema lõpetuseks peab mainima, et üks erandlik näide naistele omasest ülitundlikkusest - rikkast daamist, kes ei saa magada, kuna tema voodis on mõned niidijupid, - on leitud ka kaugelt Hiinast (Ting 1978: nr 704) - lõunaprovintsi Guangdongi 20. sajandi nalja- 
lugude kogust. Sellel piirkonnal on sajandeid olnud tihedad kaubandussuhted India, Pärsia ja Araabia maadega ning ta on olnud nendest maadest pärit narratiivide väravaks Hiinas. ${ }^{18}$

Kui võtame kokku kirjalikud tõendid ülitundlikkuse motiivi kohta, näib, et sünge pärimus siirast või teeseldud tundlikkusest kui naiseliku kõlvatuse ja pahelisuse väljendajast on valdavam kui lõbusad lood naiseliku hapruse äärmustest.

\section{Läbinägelikud mehed}

Ülitundlikkuse motiivi mainitakse mõnikord üheaegselt erakordse arukuse motiiviga (Christensen 1936: 251; Christensen 1906: $172 \mathrm{jj}$; Bolte \& Polívka 1918: 332; Schick 1934: 142-145). Neist esimest käsitatakse kui naistele omast puudust ja teist kui mehelikku saavutust. Viimane moodustab osa jutust kolmest (või neljast) nutikast vennast (AT 655: Taibukad vennad; AT 655A: Eksinud kaamel ja nutikad järeldused) (Ranke 1979) ning on oluliselt selgepiirilisem pärimus kui ülitundlikkuse motiivi sisaldavad jutud.

Kõige silmapaistvamalt on see esindatud mitmetes Vetāla kahekümne viie jutu (Schick 1934: 90-136;19 Ranke 1979: 880; Uhle 1924: 120-126 (nr 23); Ruben 1964: 139-141 (nr 11); Oesterley 1873 (nr 23); Behadur Kalee-Krishen 1834 (nr 23); Barker 1855 (nr 23); Tawney 1884: 271-275 (ptk 82, nr 8)) tekstides. Antud näite puhul on esimene kolmest nutikast vennast asjatundja toidu, teine naiste ja kolmas voodite alal. Jambhaladdata tekstis väljendub motiiv järgmiselt: olles maganud kõige mugavamas voodis, kaebas voodeid tundev vend järgmisel hommikul:

Küll oli vilets säng. See juuksekarv madratsi all hõorrus mu naha üleni punaseks (Schick 1934: 94).

Siin tunneme ära printsessi herneteral. Ent hindi versioonis Baitāl Pachisi teatab voodiasjatundja lihtsalt:

Kõrgeauline kuningas! Voodilina seitsmenda voldi vahel on juuksekarv ja see torkis mu selga. Sellepärast ei saanud ma magada (Schick 1934: 122-133; Oesterley 1873: nr 23; Behadur Kalee-Krishen 1834: nr 23; Barker 1855: nr 23). 


\section{Christine Shojaei Kawan}

Antud loos rõhutatakse selgelt just läbinägelike vendade ebatavalisi oskusi ja taibukust, ehkki vahel kirjeldatakse neid ka mõnevõrra nõudlikena (vrd Ruben 1964: 140) ${ }^{20}$ Lugu kuulub idamaiste narratiivide ulatuslikku tsüklisse, mis on avaldatud Josef Schicki kaheköitelises väljaandes (Schick 1934; 1938) ja sisaldab jälgede ajamise (tuntud elevant-või-kaamel-katse), päritolu avastamise (ingl $\mathrm{k}$ bastard proof - sohilapsekatse), õilsameelsuse (AT 976: Milline oli ôilsaim teguviis? (Schoenfeld 1990)), vääriskivi, hobuse jne tundmise katseid.

Sohilapse-katse on üks tsükli levinumaid motiive ja see on jõudnud Indiast Saxo Grammaticuse Hamleti-loosse. Printsess herneteral räägib just suursuguse päritolu teemal, sest kui selles loos osutub, et kahtlane peigmehekandidaat on tegelikult suursugust päritolu, siis päritolu avastamise (bastard proof) lugudes tuleb ilmsiks kuninga või tema naise madal päritolu, ja seda ei tehta kindlaks mitte voodikatsega, vaid nutika paljastuse abil.

Olulise tähtsusega on õhtumaises kirjanduses ka jälgede ajamise lood, mida mainitakse esmakordselt 3. sajandi budistlikes allikais: Euroopa kirjandust läbivad need alates Christoforo Armeno kuulsast Peregrinaggiost, ning veelgi kuulsamast Voltaire'i Zadigi 3. peatükist kuni Edgar Allan Poe ja Arthur Conan Doyle’i jutustusteni - teisisõnu on need lood "juhuse läbi tehtud avastustest" (tales of 'serendipity"1) detektiivi romaanide eelkäijad (Messac 1929: 17-38; Murch 1958: 68 jj, 177; Wölcken 1953: 17 jj; Shojaei Kawan 1996: 446).

Käsiteldava jututsükli asjatundjatest vendade erakordne läbinägelikkus näib mõnevõrra eluvõõras, ent ometi on oma ala asjatundjatel tähtis roll ka tänapäeva ühiskonnas - kõrgklassis gurmaanid, ${ }^{22}$ veiniasjatundjad, parfüümiasjatundjad ja muusikaeksperdid; tavatasandil meenutab see aga näiteks suurejoonelisi kihlvedusid Thomas Gottschalki populaarses telešõus Wetten $d a \beta \ldots .^{23}$ Saksa televisioonis, kus veeti kihla näiteks selle peale, kes tunneb tantsu ära ainult sammude kaja või hundirattaid tegeva lapse tema varju järgi, kes suudab teha automarkidel vahet pesuharjade tekitatud hääle järgi autopesulas ${ }^{24}$ või eri marki tualettpaberitel puudutuse või maitse järgi. ${ }^{25}$ Mõned jälle sooritasid keerukaid aritmeetilisi tehteid või paistsid silma hea mäluga - ja enamik kihlavedajaist võitis kihlveo. Sarnaselt Guinnessi rekordite raamatus dokumenteeritud enamasti kasutute saavutustega, demonstreerivad ka kihlavedajad, et keskpärased inimesed suudavad endas arendada harukordseid võimeid. ${ }^{26}$ 
Mis puutub kolme osava venna loos voodite asjatundjasse, siis on tähelepanuväärne, et see motiiv esineb suuresti vaid Vetāla kahekümne viie jutu traditsioonis, samuti Kathāratnākaras (Schick 1934: 134-136; Hertel 1920: 248 jj) ning mõnes idaindia (Vries 1928: 120122, nr 121), kambodža (Gaudes 1987: nr 34) ja himaalaja ${ }^{27}$ (Lorimer 1935: 405-409; Minajev 1876-1877) rahvajutus. Huvitaval kombel on himaalaja variandid asetatud pruudi eest võitleva peigmehe proovilepaneku konteksti. Ühe vooditundja-motiivi näite leiame selle tavapärasest esinemisalast palju kaugemalt, nimelt midraši Rabi nutulauludest (5. sajandist): lugu on osa üheteistkümnest mõistujutust koosnevast tsüklist, mis ülistab jeruusalemlaste tarkust ja pilab ateenlasi. See on arvatavasti vanim seda motiivi sisaldav versioon jututüübist AT 655/655A (eriti arvestades asjaolu, et Vetāla kahekümne viie jutu dateering on ebamäärane). Samas kui voodiasjatundja vennad läbivad tänu oma erilisele läbinägelikkusele toidu, veini ja madala päritolu äratundmise (bastard proof) katsed probleemideta, siis voodieksperdi võimed ei ole mingil moel ebatavalised - kes meist ei magaks ebamugavas voodis halvasti (Hasan-Rokem 2000: 47 jj; Schick 1934: 246-248).

Kui voodieksperdi kaks venda, toiduekspert ja naistetundja, jäid läbivateks figuurideks osavate vendade juttudes ka väljaspool india kultuuriareaali, siis voodiekspert kadus areenilt ja läbis iseseisva arengutee mõningates Seitsme targa raamatu (Book of the Seven Sages) euroopa versioonides. Jutu sissejuhatavas osas panevad koduõpetajad printsi proovile, et teada, kas nende õpilane on teadustes edasi jõudnud, ja asetavad iga voodijala alla puulehe. Järgmisel hommikul üles ärgates tõestab prints oma peent taju hüüatusega:

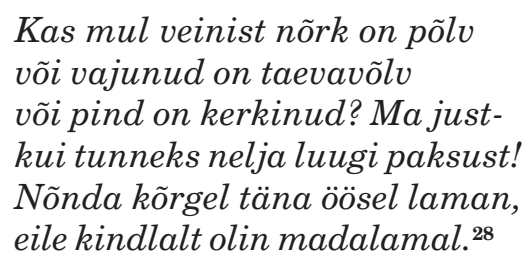

Antud episoodile silmatorkavalt lähedase paralleeli on jäädvustanud üks 20. sajandi teisel poolel Iisraelis elanud pärsia immigrant. See räägib kaliif Hārūn ar-Rašĩdi troonipärija määramisest: Hārūn ise eelistaks oma vanimat poega, kuid tema pärsia päritolu suurvesiir soovitab nooremat. Kokkuleppele jõudmata otsustavad nad poisid proovile panna. Kui printsid söövad lõunat, hiilib kaval suurve- 


\section{Christine Shojaei Kawan}

siir salaja nende klassiruumi ja paneb vanema poja vaiba alla katusekivi, teise poja vaiba alla aga paberilehe. Teine poeg märkab muutust kohe ja pärib:

\section{Mis on juhtunud? Kas mina olen kasvanud või on lagi mada-} lamale tulnud?

Tänu terasusele saabki temast Hārūni täieõiguslik pärija. ${ }^{29}$ Sõnad Kas taevas (lagi) on madalamale tulnud või maa tõusnud (mina olen kasvanud) on iseloomulikud teistelegi sama Seitsme targa episoodi rahvalikele mugandustele. Ühes Aarne-Thompsoni jututüübi 655/ 655A Mallorca variandis ütlevad sedasama kõik kolm terast peigmehekandidaati, kellega kuningas teeb paberikatse (selles loos ka voodikatse) (Alcover 1953 II: 141-147; vrd Schick 1938: 445) ning ühe usbeki jutu vastavas episoodis ütleb seda nupukas töömees, kes kandideerib vesiiriks ja kelle panevad proovile kadedad kaasvesiirid (Afzalov \& Hussainova 1963: 389-401). Paroodilise detektiivfilmi Murder by death (Mõrv surma läbi) ${ }^{30}$ lõpul teeb analoogse märkuse Hercule Poirot, kui lagi vajub tegelikult alla eesmärgiga tappa tema ja ta teenija. Ja lõpetuseks esineb sama motiiv ka ühes kurioosses lühianekdoodis, mis pärineb Afganistanist: Mirza Zakai, kes on seotud šahh 'Abbāsiga (võimalik, et on mõeldud 'Abbās Suurt, kes valitses Pärsia impeeriumi aastail 1587-1629), on segaduses, sest koristaja on jätnud kabinetis paberi tema toolile. ${ }^{31}$

Võimalik, et narratiivid on mõjutatud Seitsme targa raamatu rahvaväljaannetest. Vähemalt Iirimaal ilmus küll arvukalt odavas väljaandes Seitsme targa raamatu ümberjutustusi. Need kuulusid ka 18.-19. sajandil iiri katoliiklaste asutatud ebaseaduslike koolide (nn hedge school - võsakoolid) (Dowling 1935: 81) õppekirjanduse hulka - sealtkaudu võis proovilepanemise episood Seitsme targa lugudest jõuda rahvapärimusse.

20. sajandi keskel on Iirimaa lõunakrahvkondades jäädvustatud neli varianti loost, mille peategelaseks on kreeka filosoof Aristoteles: Aristoteles veedab kõik ööd taevatähti vaadeldes. See ajab tema naisel hinge täis ja too paneb salaja iga lauajala alla hõbemündi, mille tulemusel mees jõuab järeldusele, et taevakehad kas tulevad maa poole või suur maa tõuseb ülespoole (või taevas on kas maa poole liikunud või maa on taeva poole tõusnud). Nii suudab naiselik tarkus naeruvääristada tarka meest. Bo Almqvisti arvates on iiri folklooris küllaltki levinud motiiv, et Aristoteles ei suutnud mõista 
kolme asja: tõususid ja mõõnasid, mesilaste tööd ning naiste mõttelaadi. ${ }^{32}$ Nutikuse proovilepaneku lugudes on haruldane, kui taibukas mees osutub küll ebatavaliselt teraseks, kuid tehakse ikkagi narriks.

\section{Kavalad kassid ja segaduses herneotsijad}

Kolmas motiiv jutus Printsess herneteral on pruudi proovilepanek - rahvalikes narratiivides nii sageli esinev motiiv, et näited on siin ülearused (vt Moser-Rath 1979). Hiljuti tõlgendas Saksa feminismiloolane Bea Lundt muinaslugu Printsess herneteral ühe Seitsme targa raamatust episoodi (tema arvates on see klassikaline kombinatsioon initsiatsiooniriituseks (Lundt 1999: 252)) võtmes kui lugu, mis rõhutab kuningliku paari (eriti aga kuninganna) soojätkamisrolli tähtsust ning kui kuningliku pruudi proovilepanekut selleks ülesandeks valmisolekuks:

Tänu eriliselt õrnale nahale võib printsessi pidada tundeliseks partneriks armastuses. Kuninganna rolliks peetakse aga ennekõike rasestumist, sünnitamist ja lastekasvatamist, et kuningliku perekonna valitsustee jätkuks. Tütarlast, kes pidi saama troonipärija kaasaks, ei pandud proovile mitte niivõrd tundlikkuses, vaid tema sobivuses (Lundt 1999: 255).

Bea Lundti arvates edastab vana kuninganna hernekatsega justkui sümboolse sõnumi: kuninganna soov on miniat eluraskusteks ette valmistada, sest abielu ei saa olema kerge ja öised mugavused on piiratud (Lundt 1999: 257). Lundti viide pärineb keskaegsete kuningannade elutingimustest. Et meil tuntud Printsess herneteral variandid pärinevad 19. sajandist, ei saa neid võtta sõna-sõnalt - need sisaldavad liiga palju irooniat, mis balansseerib tõe ja vale, olemusliku ja näiva, tundlikkuse ja dekadentsi piiril. Ja kuigi vihjatakse loomulikult ka tulevase kuninga pruudi soojätkamisvõimele, on olulisem siiski sugupuu puhtuse säilitamine - tundlikkust tajutakse eeskätt kui kõrgest soost päritolu tunnust, mitte niivõrd kui väärtust iseenesest.

Uurijad, kes ei uskunud, et H. C. Andersen oli seda lugu kuulnud nooruses ${ }^{33}$ kas ketrustoas või humalakorjamise ajal, nagu ta ise kinnitas (Eventyr 1990a: 169), oletasid hoopis järgmist: 


\section{Christine Shojaei Kawan}

Palju tõenäolisemalt [---] kuulis ta seda oma isalt, kes luges talle tihti ette jutte nii Idamaade kui ka Euroopa kogumikest (Penzer 1923: 290; Christensen 1906: 169).

Kuid seni pole tulnud päevavalgele ühtegi kõnealuse loo trükivarianti, mis oleks võinud olla sellele vaesele kingsepale kättesaadav. ${ }^{34}$ Ja kuigi taani rahvatraditsioonist pole jäädvustatud ühtegi analoogset juttu, on teada mõned huvipakkuvad lood Skandinaaviast (peamiselt Soomest ja Rootsist), mida võidi rääkida ka Taanis ja mis võivad olla inspireerinud H. C. Anderseni Printsessi herneteral.

Need on variandid Aarne-Thompsoni jututüübist 545A (Kassi loss) (Köhler-Zülch 1993: 1126-1131), mida võiks mugavuse mõttes nimetada jututüübi AT 545B (Saabastega kass) (Köhler-Zülch 1993: 1069-1083) üheks formuleeringuks, kus peategelane on nais-, mitte meessoost ja mis sisaldab paari erilisemat motiivi, kuid on muus osas ainese ja struktuuri poolest sama. Mitmetes Skandinaavia Kassi lossi muinaslugudes on vaese tüdruku saatjaks abistajaloom, enamasti kass, mõnikord ka koer. Kassi soovitusel saabub tüdruk lossi ja teeskleb, et on kõrgest soost. Vana kuninganna paneb ta salaja, tihtipeale ka korduvalt proovile, korraldades juba tuttava voodikatse, mis võib varieeruda madratsi alla peidetud eseme osas, milleks võib olla kudumisvarras, hernetera, heinakõrs vm. Tüdruk magab suurepäraselt, aga nagu alati, järgib ta kavala kassi soovitust ja kaebab, et on veetnud kohutava öö (Christensen 1906: 169 jj; Bolte \& Polívka 1918: 331 jj; Köhler-Zülch 1993: 1128; Hodne 1984; ${ }^{35}$ vrd Rausmaa $\left.1988^{36}\right){ }^{37}$

Vahetevahel on voodikatset korraldatud ka meessoost jutukangelasele (Imbriani 1877: $\mathrm{nr} 10^{38}$ ). ${ }^{39}$ Seoses Õhulossi lugudega (Bottigheimer 1996) võisid jututüübi AT 545B variandid luua soodsa pinnase hoopis teisele, kuid analoogsele jututüübile, milleks on nn herneotsija ja oakuninga lood, mida on liigitatud mitut moodi, nt AT 545C* (Kehkenpüks leiab pruudi) ja AT 545D*(Oakuningas) või Reginetta Haboucha (1992) **859E (Vaene kosilane). Kuigi herneotsija ja oakuninga lugu pole eriti levinud, on seda jäädvustatud erinevais maailma paigus. Jutt kõneleb vaesest noormehest, kes leiab herne või oa ja usub, et see on hinnaline. Noormees saabub lossi, kus ta pannakse õlgede peale magama. Seal tundub talle, et hernes või uba on kaotsi läinud. Noormees pöörab end asemel ühelt küljelt teisele, et seda üles leida, ja arvatakse seetõttu olevat kõrgest soost inimene, kes pole harjunud õlgedel magama. Järgmisel ööl antakse talle 
voodi, kus ta magab hästi, sest tema hernes on kindlas kohas, sellega kinnitab ta oma aadellikku päritolu ja saabki printsessi endale naiseks ${ }^{40}$ (Scherf 1995: 838-840). ${ }^{41}$

Vastupidiselt Kassi lossi tegelastele, kelle teod on enamasti sihiteadlikud ja arukad, tegutsevad selle vastuolulise $100^{42}$ tegelased nii peategelane kui ka kuningas, kes tahab tütart mehele panna, ja kuninga teenrid - pigem rumalate otsuste ajel.

\section{Hans Christian Andersen ja vennad Grimmid}

Et Printsess herneteral keskse motiivi kirjalikud eelkäijad on muinasjutust nii vaimult kui ka sisult kaugemad kui hernekatse motiivi sisaldavad Kassi lossi lood, ja et viimased paistavad esindavat väljakujunenud, kuigi ehk vähelevinud traditsiooni - mitmed rootsi variandid on enam-vähem H. C. Anderseni kaasaegsed ja üks neist isegi tema kirjapanekust varasem (Hyltén-Cavallius \& Stephens 1844: $\mathrm{nr} 12)^{43}$ - , ei ole liiast oletada, et H. C. Andersen on selle loo leidnud ja seda lühendanud, et avaldada see oma nime all (vrd Liungman 1961: 152; Brix 1907: 208). ${ }^{44}$

H. C. Anderseni muinasjutt erineb rahvajuttude traditsioonist mitmes asjas. Siin kõneldakse pigem tunnetamisest kui tegutsemisest, kuigi jääb kaheldavaks, kas tunnetuseni on üldse võimalik jõuda. Juba teksti alguses on öeldud, et ta tahtis endale printsessi naiseks saada, aga see pidi tõeline printsess olema. Siiski ei selgu, mida mõistetakse tõelise printsessi all: oma otsingutel leiab ta, et printsesse oli küllalt, aga ei ole selge, kas nad on ikka tõelised printsessid. Veidi hiljem osutub linnavärava juures vihmas seisev tütarlaps otsekohe printsessiks. Kuid kas on tegu tõelise printsessiga? Nagu paljud teisedki muinasjutukangelased, asus meiegi prints otsinguretkele, kuid see lõppes täiesti edutult. Kui tavaliselt saavad otsinguretkele suundunud kangelased jagu koletistest ning leiavad ebatavalisi abistajaid, aardeid ja printsesse, siis see vaene prints leiab eest vaid pettumusi - seega on tegemist väga andersenliku kangelasega. Šveitsi keeletadlane Jean-Michel Adam kirjeldab printsi kannatusi kui semioloogilist haigust: tajudes, kui raske on omandada sotsio-sümboolseid reegleid, saab ta teadlikuks nende võimalikust pöörduvusest; häirituna pinnapealsusest, elab ta, umbusaldades verbaalseid ja mitteverbaalseid märke (Adam 2000: 11).45 Lõpuks aitab vana kuninganna tal paranoiast vabaneda salasepitsu- 


\section{Christine Shojaei Kawan}

se abil, mis aitab noormehel teha vahet ehtsa ja võltsi vahel - nii leiab ta ema abiga tõelise printsessi, kelle päritolu on n-ö tõendatud (Adam 2000: 12).

Hans Christian Andersen esitab tõestamise käiku teatud irooniaga: autor väidab, et eset, mida kasutati kuninglikuks voodikatseks, ehk siis hernest, võib veel tänapäevalgi muuseumis näha - kui keegi pole seda juhtumisi ära võtnud - ning külvab sellega taas kahtlust juba usaldusväärseks muutunud loosse. Lõpetuseks nimetab Andersen kogu lugu tõsilooks (taani k en rigtig Historie) analoogselt sõnapaariga rigtig Prindsesse (Eventyr 1963: 41 jj; vt ka lisa 1) - seda lõpulauset See, det var en rigtig Historie! (Eventyr 1963: $41 \mathrm{jj}$ ) tõlgitakse, tihti ka irooniliselt: Näed sa siis - see on tõestisündinud lugu (Andersen 1987: 64), inglise k You see that was a true story (Andersen 1980: $11 \mathrm{jj}$ ); saksa $\mathrm{k}$ Sieh, das war eine wahre Geschichte (Andersen 1847: 63; Andersen 1850: 297). ${ }^{46}$

Niisiis, kui eeldada, et H. C. Anderseni muinasjutu Printsess herneteral taga peituv narratiiv on hernekatse motiiviga Kassi lossi variant, ning et $\mathrm{H}$. C. Andersen ise on lugu lühendanud ja muutnud abielluva peategelase osas, siis oleks Printsess herneteral üsnagi õelavõitu tekst: prints abiellub noore neiuga, kes pannakse proovile ja kes osutub seeläbi tõeliseks printsessiks, siiski, hoolimata kõigest on neiu petis, ja ainus, kes seda teab, on kõiketeadev jutustaja. Jutustaja seda lugejaile ei avalda, vaid veab neid pidevalt ninapidi, mängides sõnadega õige ja tõeline (taani riktig ja virkelig). Siiski tundub kogu lugu õigetest ja tõelistest printsessidest olevat vaid irooniline ettekääne. Ja sellest seisukohast ei tundugi printsi paranoia haiglane, vaid õigustatud.

On võimalik ja isegi tõenäoline, et H. C. Andersen on võtnud episoodi Kassi lossist ja avaldanud selle oma Printsess herneteral loona, aga mõnede (tegelikult küll väga väheste) muude variantide olemasolu paneb mind selles kahtlema.

Neist kõige silmapaistvam on vendade Grimmide versioon Die Erbsenprobe (Hernekatse), mille on kirja pannud Wilhelmi poeg Herman 1840. aastal Hessenist tundmatult informandilt. Sellekohased andmed pärinevad Grimmi töid uurinud Heinz Röllekelt. Mõistatuslikul kombel oli aastal 1840 Herman Grimm ainult 12 aastat vana ja $H$. Rölleke ei maini, et poiss on seda lugu kuulnud, vaid et ta on selle jäädvustanud. Grimmide Hernekatse avaldati 1843. aastal Kodumuinasjuttude (Grimm 1843b: nr 182; Grimm 1980: 418-420)47 viiendas väljaandes. ${ }^{48}$ 
Aasta hiljem kirjutas H. C. Andersen - kes oli solvunud, sest suur saksa "jutuvestja" (Jacob?) Grimm ei teadnud tema nimegi, kui H. C. Andersen teda külastada tahtis, - sellest mõnitavalt oma isalikule sõbrale Jonas Collinile, mainides, kui naeruväärne on see, et üks tema "originaalidest" (s.t Printsess herneteral) leidub Grimmide kogus taani muinasjuttude esindajana (Topsøe-Jensen et al. 1945: 24749), ja nagu kirjas järgneb, et ta võiski sellest Berliinis juttu teha. Seejärel jätsid vennad selle variandi Kodumuinasjuttude kuuendast trükist välja. Üldiselt on seda peetud teksti H. C. Andersenile omistamise tõendusena (Christensen 1906: 169; Bolte \& Polívka 1918: 331; Penzer 1923: 291), aga et neil polnud lugudest puudus, võisid Grimmid nii toimida ka praktilistel kaalutlustel. ${ }^{50}$

H. C. Anderseni lugu avaldati 1835. aastal ja tõlgiti saksa keelde 1839. aastal (Scherf 1995: 943; Uther 1993: 368): ühelt poolt tundub aasta (või isegi neli aastat, kui kahelda H. Rölleke informatsioonis, et lugu on kirja pandud 1840. aastal) esmapilgul üsna lühike aeg, et muutuda osaks traditsioonist (Christensen 1936: 257), kuid teiselt poolt hakkas Hans Christian Andersen 1835. aastast koguma kuulsust, ta oli Saksamaal väga populaarne (Nielsen 1995: 82-84; Topsøe-Jensen et al. 1945: $246 \mathrm{jj}$ ) ning tema muinasjutud ja lood levisid kiiresti. Pealiskaudsel vaatlemisel tunduvad H. C. Anderseni ja vendade Grimmide versioonid Printsessist herneteral väga sarnased, mida ka kommenteerijad tavaliselt rõhutavad. Siiski esineb neis ka olulisi erinevusi, nagu Jean-Michel Adam on näidanud tekstide lingvistilise käsitluse kaudu (Adam 2000: 5 jj, 13 jj), ja need ilmnevad samuti ka rahvajututraditsiooni pinnalt.

Ka vendade Grimmide lugu algab printsist, kes ihkab abielluda, kuid õige pea keeratakse rahvajutu reeglid pea peale. Kuningas, tema isa, saadab laiali avaliku teate, ja prints, ainus poeg, jääb otsinguretkele suundumise asemel koju sobivaid printsesse ootama. Talle tuleb end esitlema hulk meeldivaid kandidaate, aga kui neilt küsitakse sugupuu või põlvnemise kohta, siis selgub, et kellegi soontes ei voola kuninglikku verd. Lõpuks tekib printsil kohutav hirm, et ta ei leiagi endale naist. Naisekandidaatide kutsumine õukonda end esitlema on muidugi rahvalikus narratiivis üsna tuntud, aga Hernekatse puhul on soorollid vahetatud: tavaliselt otsitakse niiviisi kuningatütardele meest, kuningapojad ja meeskangelased aga võtavad tavaliselt initsiatiivi enda kätte. 


\section{Christine Shojaei Kawan}

Nagu H. C. Anderseni versioonis, on ka vendade Grimmide jutus pöördepunktiks tormine ja vihmane õhtu. Ilus tüdruk koputab palee uksele. Ta ütleb:

"Ma tulen väga kaugelt ja olen vägeva kuninga tütar. Kui sõnum teie poja pildiga saabus minu isa kuningriiki, tundsin kohe armuleeki endas süttimas ja asusin kähku teele [---]".

"Ei tahaks hästi uskuda," ütleb kuningas, "sest sa ei paista üldse kuningatütre moodi. Kuidas reisib printsess üksinda, ilma saatjateta ja on nii halvasti riides?"

"Kui saatjad oleksid kaasa tulnud, oleksin hiljaks jäänud," vastab tüdruk, "ja päike on minu riideid pleegitanud ja vihm on neist värvi välja pesnud. Kui te ei usu, et ma olen printsess, saatke teade minu isale."

"See on liialt vaevanõudev," ütleb kuningas. "Minu esindus ei saa nii kiiresti reisida kui sina [---] ja aastaid läheks mööda enne, kui nad tagasi pöörduvad. Kui ei ole muid võimalusi tõestada, et sa oled printsess [---], mine parem kohe koju."

"Las ta jääb," ütleb kuninganna. "Ma panen ta proovile ja kohe saame teada, kas ta on printsess."

See on mitmel põhjusel tähelepanuväärne stseen. Esiteks, vahetatud soorollide poolest: on ebatavaline, et kangelanna pöördub veel tundmatu kaasa otsinguile - tavaliselt teeb naine seda siis, kui partner on ta juba korra käest lasknud - , ja samavõrra ebatavaline on, et kangelanna armub tundmatusse mehesse, olles näinud vaid tema pilti või saanud tema kohta mingi muu vihje. Rahvajuttudes on selline käitumine armusasjades iseloomulik just mehele - ainuke erand, mis mulle meenub, on lugu Laura Gonzenbachi sitsiilia kogumikust, kus printsess lõhub ühe vanaeide kannu ja saadetakse otsima kuningas Chicchereddut, oma tulevast abikaasat (Gonzenbach 1870: $\mathrm{nr}$ 12). Vastupidiselt Grimmide kangelannale, kes on printsiga kohtumiseks võtnud ette pika reisi, tundub H. C. Anderseni printsess olevat jõudnud printsi lossi juurde juhuslikult.

Teiseks, ajalise kestuse liigne ebamäärasus annab vendade Grimmide jutu vastavale osale sürrealistliku alatooni: kui traditsioonilistes juttudes kestavad otsinguretked tavaliselt väga kaua (näiteks seitse aastat), siis vendade Grimmide muinasjutus reisib printsess välgukiirusel. Ta väidab, et kui saatjad oleksid kaasas olnud, oleks ta hilinenud, aga kui uskuda kuninga sõnu selle kohta, kui kaua kulunuks aega tema saadikutel, siis vältaks teekond peaaegu igaviku. 


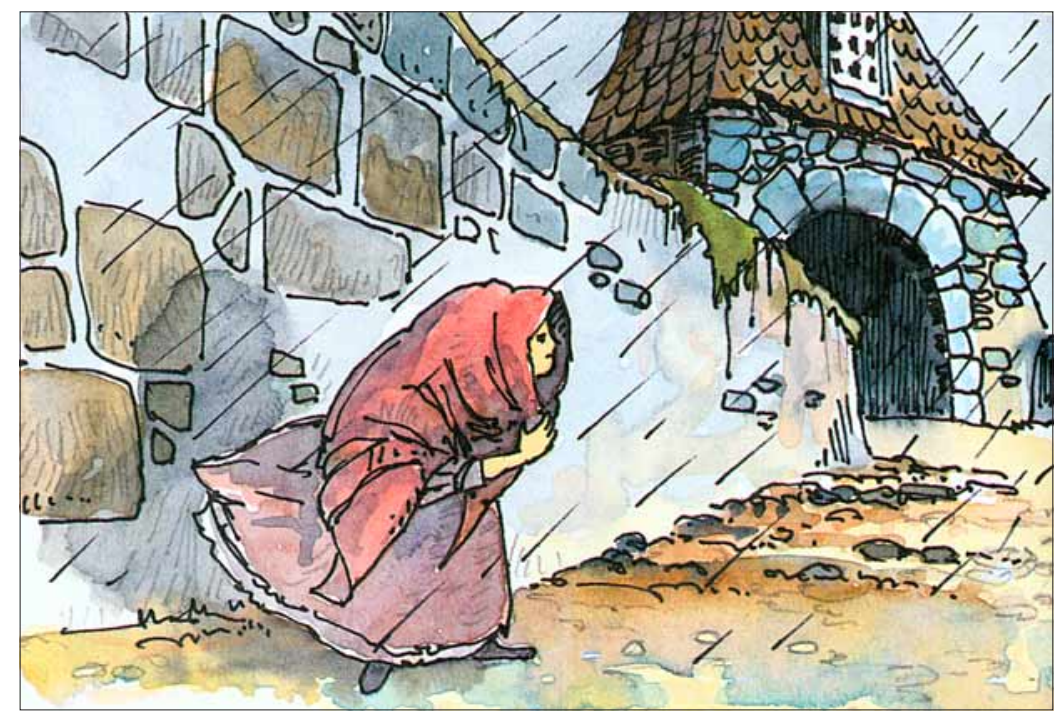

Joonis 1. Maan Janseni illustratsioon Hans Christian Anderseni muinasjutule Printsess ja hernetera. Tallinn 2001.

Selles dialoogis loovad vana valitseja ja kahtlustäratav printsessikandidaat fantastiliselt absurdse tasandi, millel nad oma vastandlike huvide kaitseks kokku puutuvad: kuningas nõuab, et tütarlaps lahkuks, ent tütarlaps tahab jääda. Siinkohal sekkub aga kuninga abikaasa ja teeb ettepaneku tütarlaps proovile panna, s.t ta asendab vankumatu tõenduse millegagi, mida võib pidada kuninglike perekondade koduseks abinõuks.

Kolmandaks vabandab tüdruk oma räsitud väljanägemist tuule ja vihma kätte jäämisega. See kõlab nagu Kolme apelsini muinaslugu (AT 408) (vrd Shojaei Kawan 2000; Goldberg 1997), mis on väga laialt levinud Vahemere ääres ja Idamaades: mustanahaline orjatar astub kangelanna asemele, väites, et päike, tuul, kastemärg ja vihm on ta välimust muutnud. Vabandused esitatakse sageli traditsioonilises värsivormis, nagu ühes katalaani jutus: el sol y la serena / fan tornar la gent morena (Amades 1950: $\mathrm{nr}$ 12). Traditsiooniline vabandusvormel Kolmes apelsinis pärineb töölisnaiste, eriti aga lõunamaade talunaiste põlvkondade vältel omandatud kogemusest: päike ja halb ilm teevad naise inetuks, samas kui pehme valge nahk on kõrgklassi privileeg. Niisiis, lisaks vendade Grimmide kangelanna rännakut 


\section{Christine Shojaei Kawan}

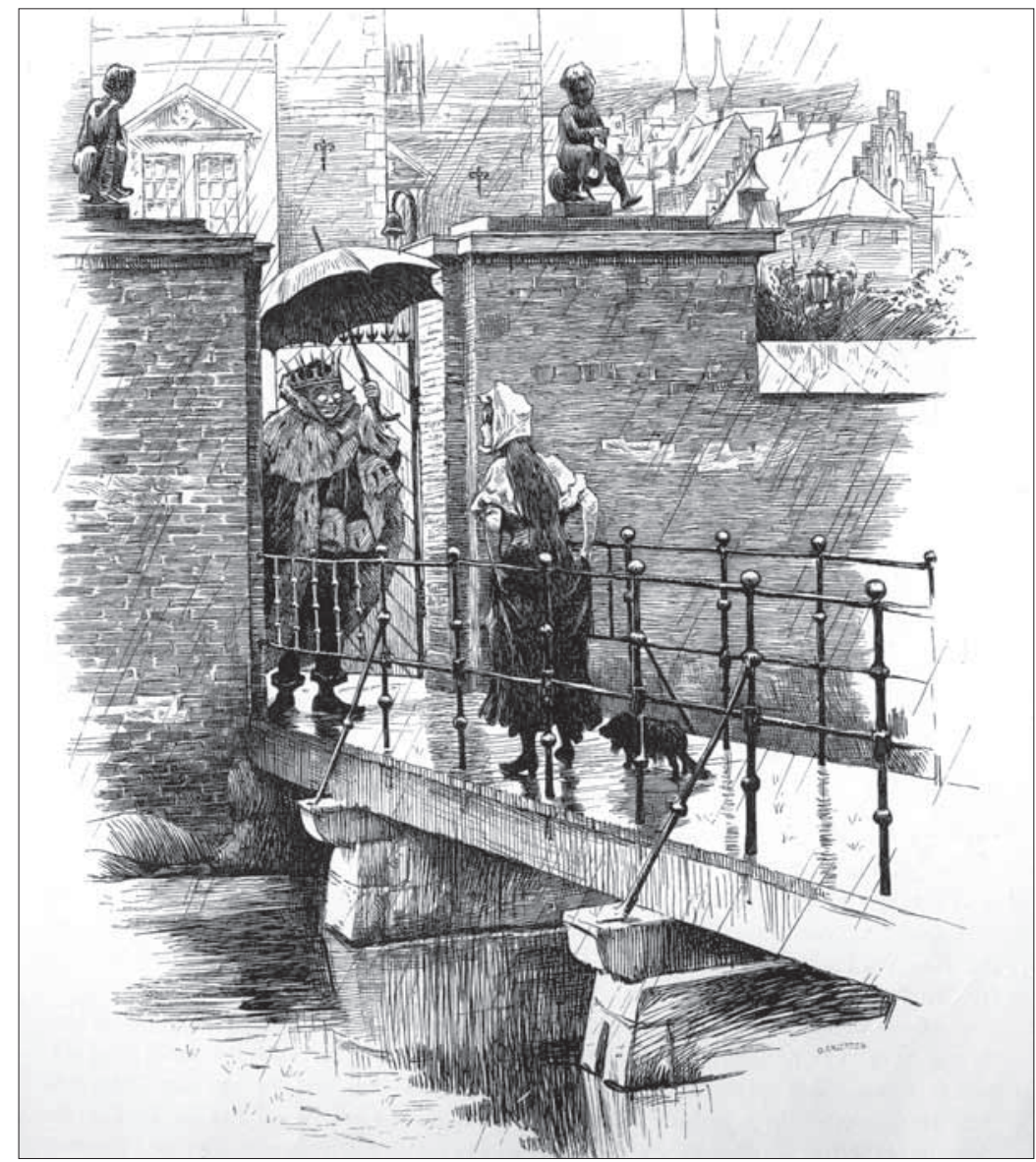

Joonis 2. Hans Tegneri illustratsioon Hans Christian Anderseni muinasjutule. Stuttgart 1900.

ümbritsevatele kahtlustele, osundab ka tema vabandus võimalusele, et tütarlaps võib olla petis.

Hans Christian Anderseni ja vendade Grimmide lugude võrdlusest selgub, et nad võisid olla teineteisest sõltumatud. Pole ka välistatud, et sedalaadi lühilood, muu hulgas näiteks ka kaks leedu lühijuttu (Basanavičius 1993: nr 79; Jurkschat 1898: nr 45"51), mis peale Grimmide versiooni on ainsad autori poolt loetud tekstidest, mida saab nimetada Aarne-Thompsoni jututüübi 704 variantideks, mitte 
üksnes H. C. Anderseni muinasjutu ümberjutustuseks, võisid levida juba enne H. C. Anderseni loo ilmumist. ${ }^{52}$ Siiski tundub mulle, et nii Grimmide jutt kui ka leedu lood põhinevad H. C. Anderseni kirjutatul, ent jutustajad on neid töödelnud üksteisest sõltumatult, ja loomulikult võib iga jutu puhul mängus olla mitu jutustajat.

H. C. Anderseni Printsess herneteral on täiuslik meistriteos, kuid ka üks leedu variantidest (Basanavičius 1993: nr 79; Jurkschat 1898: nr 45; vt ka lisa 3) on kunstiline ja hästi üles ehitatud: prints ei ole enam tegutsev figuur - teda mainitakse vaid möödaminnes kui isikut, kes kavatseb abielluda. Jällegi on kuningas see, kes oma pojale pruuti otsib, sellist pruuti, kes oleks kirjeldamatult õrn. Kuninganna on täiesti kadunud, pruudi panevad proovile nemad - teenrid või ametnikud, kes täidavad kuninga käske. Ja kui H. C. Anderseni printsess karjatab ganske forskrækkeligt! (eesti k 'täiesti kohutav!'), siis leedu printsessikandidaadid ütlevad oi, kui pehme ja mõnus, välja arvatud viimane, kes osutub võitjaks ja kes jääb tagaplaanile ja kellest kõneldakse vaid kaudses kõneviisis.

Sellised erinevused ei välista siiski kuidagi seost Hans Christian Anderseni looga - andekad jutustajad loovad oma "alliktekstid" ja käsitlevad materjali omal viisil, nagu toimis ka H. C. Andersen ise lugudega, mida ta mäletas lapsepõlvest ja mille kohta ta ütleb selgesõnaliselt:

Ma olen neid jutustanud omal moel, lubanud endale mis tahes muutust, mida pidasin sobivaks, et tuhmunud kujutluspildid eredateks muutuksid ${ }^{53}$ (Eventyr 1963: $19 \mathrm{jj}$; vt ka Andersen $\left.1847^{54}\right)$.

On tõesti üllatav, kui kangekaelselt on salatud, et Hans Christian Andersen võis Printsessi herneteral üle võtta rahvatraditsioonist, arvestades, et ta tunnistab end olevat teinud igasuguseid muutusi $^{55}$, ja väidab sealsamas, et on mitmed teised lood täiesti ise välja mõelnud, samuti sedagi, et on Keisri uued rõivad mugandanud otse Don Juan Manueli keskaegsest hispaaniakeelsest kogumikust - allikate osas ei paista H. C. Andersenil olevat tekkinud mitte mingisuguseid ideoloogilisi probleeme.

Grimmide versiooni Printsessist herneteral peetakse üldiselt H. C. Anderseni versiooni varjuks (Christensen 1936: 257; Penzer 1923: 291). Alles hiljuti vaidles sellele vastu Jean-Michel Adam, kes 


\section{Christine Shojaei Kawan}

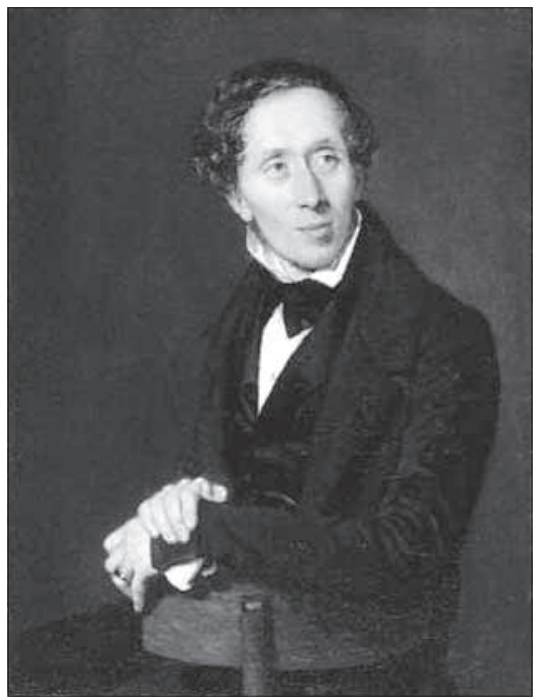

tõi välja Grimmide muinasjutu tugevad narratiivsed küljed, rõhutades ühtlust ja selgesõnalisust tegevuse sidumisel, samuti selle emantsipeerunud, peaaegu feministlikku tegelaskuju (Adam 2000: 13 jj). Siiski näib see mulle mõnevõrra tasakaalustamata loona: esimene osa on nii sisult kui ka stiililt ebatraditsiooniline ja originaalne - eriti kuninga ja tütarlapse dialoog, mis on täiesti võrratu -, teine osa aga tavalisem, kusjuures kogu lugu on täis pikitud 19. sajandile stereotüüpseid väljendeid. Seetõttu on täiesti võimalik, et tekst on kokku pandud kahest

Joonis 3. C. A. Jensen. Hans Christian Anderseni portree. 1836. erinevast loost, mida on jutustanud eri inimesed. Tugevalt kunstipärase dialoogi kuninga ja tütarlapse vahel väljamõtleja ei ole kindlasti seesama, kes kasutab väljendeid nagu ma tundsin kohe armuleeki endas süttimas või $k a-$ vatsusega saada tema abikaasaks. ${ }^{56}$

Võime oletada, et Wilhelm Grimm oleks oma pidevas viimistlusetuhinas sellised keelelised klišeed järgnevatest väljaannetest kõrvaldanud. Kuigi ta ilmselt polnud veel teinud teksti piisavalt stilistilisi parandusi, tegi ta kaks endale meelepäraseimat muutust - sest Wilhelm Grimmi silmanähtav püüdlus oli panna juttudesse vanasõnalisi väljendeid -, nimelt lisas ta sinna ütlemised: onnn koputab tihti uksele, sina vaid ava see ja elu pole meelakkumine $e^{57}$ (Rölleke 1988: 207; vrd ka Christensen 1936). Kui esimene neist sobib lohutuseks, mida kuninganna oma pojale pakub, siis teine passib vaevalt kokku kuninga ja tütarlapse dialoogi hoogsusega (see on ülaltoodud tsitaadist välja jäetud - kogu lõik kõlab järgmiselt:

Kui ei ole teisi võimalusi tõestada, et sa oled printsess, ei ole sinu elu siin meelakkumine ja mine parem kohe koju. 
Viimase, kuid siiski olulise asjana mainigem, et Hans Christian Anderseni mõju on tuntav ka vendade Grimmide jutus - nimelt selles, kuidas kirjeldatakse kurja ilma, mis on muuhulgas ka Anderseni lemmikteemasid, ${ }^{58}$ kuigi rahvapärimuses küllaltki ebatavaline, ${ }^{59}$ ja samuti printsessi, kes magab suletekkidel ( $E$ Edderduuns-Dyner / Decke von Eiderdunen) - käegakatsutav tõend, mis paistab loo päritolule vihjavat palju rohkem kui herneterade $\operatorname{arv}^{60}$

Olen öelnud, et Kassi lossi juttude valguses oleks Hans Christian Anderseni Printsess herneteral õel lugu, kuid siiski ei saa ma selles päris kindel olla. Viimase loo, mis meile käesolevas artiklis huvi pakub, on jäädvustanud Christian Schneller Wälschtirolis see on Alpide itaaliakeelse elanikkonnaga ala, mida tänapäeval tuntakse Trentino (Schneller 1867) nime all. Lugu räägib jällegi printsist, kes reisib ringi, sest tahab abielluda maailma kõige õrnema naisega. Õrnuse motiivid meenutavad eriti lugu nelja naise võistlusest kogumikus L'Élite des Contes: prints kohtub juhuslikult esimese naisega, kellele valmistab kannatusi, et tema toaneitsi on talt kogemata ühe juuksekarva välja kitkunud; teisega, kes jääb haigeks, sest tema voodilinades oli väike korts; ja lõpuks kolmandaga, kes jasmiiniõiega endale liiga teeb. Prints abiellub viimasega. Kuid kas see oli ikka tark tegu, tekib jutustajal küsimus?61 Õrnus võib olla märk säravast ilust ja suursugusest päritolust, ent kõik need hellitatud naised, keda praegu võib piltlikult nimetada printsessideks hernel, on eluks täiesti sobimatud. Lõppude lõpuks - kui umbusklik prints Hans Christian Anderseni või vendade Grimmide jutus abiellub petisega, siis ongi tal parem. Ta soovis küll abielluda erakordselt õrna naisega, aga sai selle asemel targa naise.

Tõlkinud Maarja Villandi

\section{Lisad}

\section{Lisa 1. Prindsessen paa Frten}

Der var engang en Prinds; han vilde have sig en Prindsesse, men det skulde være en rigtig Prindsesse. Saa reiste han hele Verden rundt, for at finde en saadan en, men allevegne var der noget $i$ Veien, Prindsesser vare der nok af, men om det vare rigtige Prindsesser, kunde han ikke 


\section{Christine Shojaei Kawan}

ganske komme efter, altid var der noget, som ikke var saa rigtigt. Saa kom han da hjem igjen og var saa bedrøvet, for han vilde saa gjerne have en virkelig Prindsesse.

En Aften blev det da et frygteligt Veir; det lynede og tordnede, Regnen skyllede ned, det var ganske forskrækkeligt! Saa bankede det paa Byens Port, og den gamle Konge gik hen at lukke op.

Det var en Prindsesse, som stod udenfor. Men Gud hvor hun saae ud af Regnen og det onde Veir! Vandet løb ned af hendes Haar og hendes Klæder, og det løb ind af Næsen paa Skoen og ud af Hælen, og saa sagde hun, at hun var en virkelig Prindsesse.

“Ja, det skal vi nok faae at vide!” tænkte den gamle Dronning, men hun sagde ikke noget, gik ind $i$ Sovekammeret, tog alle Sengklæderne af og lagde en Ert paa Bunden af Sengen, derpaa tog hun tyve Matrasser, lagde dem ovenpaa Arten, og saa endnu tyve AdderduunsDyner oven paa Matrasserne.

Der skulde nu Prindsessen ligge om Natten.

Om Morgenen spurgte de hende, hvorledes hun havde sovet.

"O forskrækkeligt slet!” sagde Prindsessen, "Jeg har næsten ikke lukket mine uine den hele Nat! Gud veed, hvad der har været i Sengen? Jeg har ligget paa noget haardt, saa jeg er ganske bruun og blaa over min hele Krop! Det er ganske forskrækkeligt!"

Saa kunde de see, at der var en rigtig Prindsesse, da hun gjennem de tyve Matrasser og de tyve Adderduuns Dyner havde merket Arten. Saa ømskindet kunde der ingen være, uden en virkelig Prindsesse.

Prindsen tog hende da til Kone, for nu vidste han, at han havde en rigtig Prindsesse, og Arten kom paa Kunstkammeret, hvor den endnu er at see, dersom ingen har taget den.

See, det var en rigtig Historie! (Eventyr 1963: $41 \mathrm{jj}$.

\section{Lisa 2. Die Erbsenprobe}

Es war einmal ein König, der hatte einen einzigen Sohn, der wollte sich gern vermählen und bat seinen Vater um eine Frau. "Dein Wunsch soll erfüllt werden, mein Sohn," sagte der König, "aber es will sich nicht schicken, daß du eine andere nimmst als eine Prinzessin, und es ist gerade in der Nähe [k]eine zu haben. Indessen will ich es bekanntmachen lassen, vielleicht meldet sich eine aus der Ferne." Es ging also ein offenes Schreiben aus, und es dauerte nicht lange, so meldeten sich Prinzessinnen genug. Fast jeden Tag kam eine, wenn aber nach ihrer Geburt und Abstammung gefragt wurde, so ergab sich's, daß es keine Prinzessin war, und sie mußte unverrichteter Sache wieder abziehen. "Wenn das so fortgeht," sagte der Prinz, "so bekomm ich am Ende gar keine Frau." "Beruhige dich, mein Söhnchen," sagte die Königin, "eh 


\section{Christine Shojaei Kawan}

du dich's versiehst, so ist eine da; das Glück steht oft vor der Türe, man braucht sie nur aufzumachen." Es war wirklich so, wie die Königin gesagt hatte.

Bald hernach, an einem stürmischen Abend, als Wind und Regen ans Fenster schlugen, ward heftig an das Tor des königlichen Palastes geklopft. Die Diener öffneten, und ein wunderschönes Mädchen trat herein, das verlangte, gleich vor den König geführt zu werden. Der König wunderte sich über den späten Besuch und fragte sie, woher sie käme, wer sie wäre und was sie begehre. "Ich komme aus weiter Ferne," antwortete sie, "und bin die Tochter eines mächtigen Königs. Als Eure Bekanntmachung mit dem Bildnis Eures Sohnes in meines Vaters Reich gelangte, habe ich heftige Liebe zu ihm empfunden und mich gleich aufden Weg gemacht, in der Absicht, seine Gemahlin zu werden." "Das kommt mir ein wenig bedenklich vor," sagte der König, "auch siehst du mir gar nicht aus wie eine Prinzessin. Seit wann reist eine Prinzessin allein ohne alles Gefolge und in so schlechten Kleidern?" "Das Gefolge hätte mich nur aufgehalten," erwiderte sie, "die Farbe an meinen Kleidern ist in der Sonne verschossen, und der Regen hat sie vollends herausgewaschen. Glaubt Ihr nicht, daß ich eine Prinzessin bin, so sendet nur eine Botschaft an meinen Vater." "Das ist mir zu weitläuftig," sagte der König, "eine Gesandtschaft kann nicht so schnell reisen wie du. Die Leute müssen die nötige Zeit dazu haben; es würden Jahre vergehen, ehe sie wieder zurückkämen. Kannst du nicht auf andere Art beweisen, daß du eine Prinzessin bist, so blüht hier dein Weizen nicht, und du tust besser, je eher, je lieber dich wieder auf den Heimweg zu machen." "Laß sie nur bleiben," sagte die Königin, "ich will sie auf die Probe stellen und will bald wissen, ob sie eine Prinzessin ist."

Die Königin stieg selbst den Turm hinauf und lie $\beta$ in einem prächtigen Gemach ein Bett zurechtmachen. Als die Matratze herbeigebracht war, legte sie drei Erbsen darauf, eine oben hin, eine in die Mitte und eine unten hin, dann wurden noch sechs weiche Matratzen darübergebreitet, Linnentücher und ein Decke von Eiderdunen [Sic!]. Wie alles fertig war, führte sie das Mädchen hinauf in die Schlafkammer. "Nach dem weiten Weg wirst du müde sein, mein Kind," sagte sie, "schlaf dich aus: morgen wollen wir weiter sprechen."

Kaum war der Tag angebrochen, so stieg die Königin schon den Turm hinauf in die Kammer. Sie dachte das Mädchen noch in tiefem Schlaf zu finden, aber es war wach. "Wie hast du geschlafen, mein Töchterchen?" fragte sie. "Erbärmlich," antwortete die Prinzessin, "ich habe die ganze Nacht kein Auge zugetan." "Warum, mein Kind, war das Bett nicht gut?" "In einem solchen Bett hab ich mein Lebtag noch nicht gelegen, hart vom Kopf bis zu den Füßen; es war, als wenn ich 


\section{Christine Shojaei Kawan}

auf lauter Erbsen läge." "Ich sehe wohl," sagte die Königin, "du bist eine echte Prinzessin. Ich will dir königliche Kleider schicken, Perlen und Edelsteine: schmücke dich wie eine Braut. Wir wollen noch heute die Hochzeit feiern" (Grimm 1980: 518-520).

\section{Tõlge:}

Elas kord kuningas, kellel oli üksainus poeg, kes tahtis väga naist võtta ning palus oma isal leida talle naine. "Su soov peab täidetud saama, mu poeg," ütles kuningas, "kuid ei tohi juhtuda, et sa naid kellegi teise kui printsessi, ent parajasti pole lähedusest ühtegi võtta. Seepärast tahan ma lasta asjast kuulutada, võib-olla annab endast teada mõni kaugem printsess." Nii saadeti välja avalik kiri ja ei võtnudki kuigi kaua aega, kui endast teatas piisavalt printsesse. Peaaegu iga päev tuli keegi, aga kui tema sünnipära ja päritolu küsiti, tuli välja, et ta polnudki printsess ja pidi tühjade kätega taas ära sõitma. "Kui nii edasi läheb," ütles prints, "siis ei leiagi ma lõpuks naist." "Rahune, mu pojake," ütles kuninganna, "kui on õige aeg, on ta kohal - onn seisab tihti ukse taga, uks tuleb vaid avada." Läks tõepoolest nii, nagu kuninganna oli öelnud.

Varsti pärast seda, ühel tormisel õhtul, kui tuul ja vihm vastu aknaid peksid, koputati tugevasti kuningalossi uksele. Teenijad avasid selle ja sisse astus imekaunis tütarlaps, kes nõudis, et ta kohe kuninga ette viidaks. Kuningas imestas hilise külastaja üle ja küsis temalt, kust ta tuleb, kes ta on ja mida ta tahab. "Ma tulen väga kaugelt," vastas tütarlaps, "ja olen vägeva kuninga tütar. Kui teade teie poja pildiga saabus minu isa kuningriiki, tundsin kohe armuleeki endas süttimas ja asusin kähku teele, et tema kaasaks saada" "Ei tahaks hästi uskuda," ütles kuningas, "sest sa ei paista üldse kuningatütre moodi. Mis ajast reisib printsess üksinda, ilma saatjateta ja on nii viletsalt riides?" "Kui saatjad oleksid kaasa tulnud, oleksin hiljaks jäänud," vastab tüdruk, "ja päike on minu riideid pleegitanud ja vihm on neist värvi välja pesnud. Kui te ei usu, et ma olen printsess, saatke saadikud minu isa juurde." "See võtab liialt aega," ütles kuningas, "saadikud ei saa nii kiiresti reisida kui sina. Inimesed vajavad selleks aega; ja aastaid läheks mööda enne, kui nad tagasi jõuavad. Kui ei ole muid võimalusi tõestada, et sa oled printsess, ei saa su elu olema siin meelakkumine, ja sa teeksid seda paremini, mida varem sa koduteele pöörduksid." "Las ta jääb," ütleb kuninganna. "Ma panen ta proovile ja peagi saame teada, kas ta on printsess."

Kuninganna läks ise üles lossitorni ja laskis uhkes toas voodi korda teha. Kui madrats oli kohale pandud, asetas ta sellele kolm hernetera, ühe ülespoole, ühe keskele ja ühe allapoole, siis pandi veel kuus pehmet madratsit nende peale, linased linad ja hahasulgedest 


\section{Christine Shojaei Kawan}

tekk [Sic!]. Kui kõik korras oli, juhatas ta tütarlapse üles magamiskambrisse. "Pärast pikka teed oled sa kindlasti väsinud, mu laps," ütles ta, "puhka ennast välja: homme räägime edasi."

Vaevalt oli päev koitnud, kui kuninganna juba üles tornikambrisse astus. Ta arvas, et leiab tütarlapse sügavas unes, kuid piiga oli ärkvel. "Kuidas sa magasid, mu tütreke?" küsis ta. "Kohutavalt," vastas printsess, "ma ei saanud kogu öö jooksul sõba silmale." "Miks siis, mu laps, kas ase polnud mugav?"- "Sellises voodis pole ma oma elus veel kordagi maganud, see oli kõva peast jalgadeni; tundus, nagu lamaksin ma paljaste herneste peal." "Ma näen nü̈̈d," ütles kuninganna, "et sa oled tõeline printsess. Ma kingin sulle kuninglikud rõivad, pärlid ja kalliskivid: ehi end pruudiks. Juba täna peame me pulmad."

\section{Lisa 3. Eine feinfühlige Prinzessin}

Ein sehr reicher König suchte für seinen Sohn eine Braut, wollte aber eine vor allen sonderliche haben, nämlich eine so verzärtelte und so empfindsame, daß man es nicht beschreiben kann. Welche durch 30 Unterbetten eine (darunter) gelegte Erbse fühlen würde, die könne seine Frau sein. Viele Prinzessinnen kamen zur Schau, jede einzelne bettete man auf die 30 Unterbetten. Frühmorgens fragte man jede, wie sie geschlafen habe. Jede antwortete:

"Sehr weich und süß habe ich geschlafen."

"Hat nichts gedrückt?"

"Ach nein! Ach nein!"

Endlich sagte, wie mir scheint, die dreißigste, sie habe einen solchen runden Gegenstand gespürt, welcher ihr nachtüber die Seite gedrückt hätte; wenn da nur nicht irgend ein Stein sich verirrt hätte. Diese gewann! (Jurkschat 1898: nr 45).

\section{Tõlge:}

Kord otsis rikas kuningas oma pojale pruuti, tahtis aga eelkõige nimelt sellise leida, kes on nii õrn ja tundlik, et seda ei saa kirjeldada. Kes läbi 30 madratsi nende alla pandud hernetera tunda suutis, see pidi tema naiseks saama. Paljud printsessid tulid end näitama, igaüks neist magas 30 madratsi peal. Varahommikul küsiti igaühelt, kuidas ta maganud oli. Kõik vastasid:

"Väga pehmelt ja magusalt magasin."

"Kas miski ei häirinud külje all?"

“Oh ei! Oh ei!" Lõpuks ütles üks, mulle tundub, et see oli kolmekümnes, ta olevat mingit ümarat eset tundnud, mis tal öö otsa vastu külge oli vajutanud -justkui oleks mingi kivi teda seganud. See printsess võitis! 


\title{
Christine Shojaei Kawan
}

\section{Lisa 4. AT 704 (Printsess herneteral) ja teiste AT 704 alla jututüübi indeksite ja analoogsete uurimuste järgi liigitatud juttude rahvusvaheline dokumentatsioon}

\begin{abstract}
Aarne, Antti \& Thompson, Stith 1961. The Types of the Folktale: A classification and bibliography. Teine, parandatud trükk. Folklore Fellows' Communicationes 75: 184. Helsinki: Suomalainen Tiedeakatemia. Nr 704. Lisaks mitmetele artiklitele ning Hans Christian Anderseni ja vendade Grimmide versioonidele on mainitud vaid üht Lundi Folklooriarhiivist (mida ma ei ole näinud) ning S. Thompsoni ja J. Balysi india kataloogist (vt allpool) pärit teksti.
\end{abstract}

Hodne, Ørnulf 1984. The Types of the Norwegian Folktale. Instituttet for sammenlignende kulturforskning B: 68. Oslo: Universitetsforlaget \& London: Global. distributor. Nr 704. Kolm viidet. Esimeses neist on teksti üksnes mainitud, mitte jäädvustatud. Kaks teist juttu on jutustanud üks ja sama jutustaja, Olav Eivindsson Austad, kes kinnitas, et on loo laenanud suulisest pärimusest; ühe tõlgenduse on jäädvustanud Torleiv Hannaas 1920. aastal ning see järgib väga lähedalt H. C. Anderseni teksti (vt ka ingliskeelset tõlget (Kvideland \& Sehmsdorf $1999 \mathrm{nr} 22$ ). Tänan Reimund Kvidelandi Bergenist temalt saadud teabe eest. Austadi teine variant, mille Knut Liestul jäädvustas 1920. aastal, on läbipõimunud Kassi lossi looga, vt Hodne (1984) nr 545B, jutt 34.

Rausmaa, Pirkko-Liisa 1988 (toim). Suomalaiset kansansadut 1: Ihmesadut. Suomalaisen Kirjallisuuden Seuran Toimituksia 482. Helsinki. Suomalaisen Kirjallisuuden Seura, lk 492 (soome variant AT 545), 500 (soome variant AT 704). AT 704 ei esine Soomes iseseisva jutuna, küll aga on AT 545 sadakonna variandi hulgas arvukalt tekste, mis sisaldavad voodikatse episoodi.

Arājs, Kārlis \& Medne, Alma 1977. Latviešu pasaku tipu rādītājs = Указатель типов латышских народных сказок = The types of the Latvian folktales. Rīga: Zinātne. Nr 704. 14 teksti Läti rahvaluulearhiividest. Riia teadlase Guntis Pakalnsi (kellele võlgnen palju tänu nende tekstide analüüsi eest minu uurimuse tarbeks) arvates on need kõik H. C. Anderseni jutu tõlgendused, mõnes järgitakse seda isegi pisidetailides, teised sisaldavad vähesel määral mitmesuguseid lahknevusi. Kõik need on kogunud aastatel 1922-1940 arvatavalt teksti kirjanduslikust päritolust mitteteadlikud koolilapsed, kelle informantideks olid enamasti vanemad ja vanavanemad. 
Kerbelytè, Bronislava 1999. Lietuviu pasakojamosios tautosakos katalogas = The Catalogue of Lithuanian Narrative Folklore 1. Vilnius: Lietuviu literaturos ir tautosakos institutas. Kaks teksti (esimene neist trükitud kaks korda). Mõlemad võivad algselt tuleneda H. C. Anderseni jutust, kuid need on, nagu Grimmide versioongi (lisa 2), piisavalt sõltumatud, et neid saaks nimetada selle variantideks (vrd lisa 3, Basanavičius (1993: nr 79), Jurkschat (1898: nr 45) ning Vilniuse Kirjanduse ja Rahvaluule Instituudi Leedu Rahvaluule Arhiivis säilitatavat suulist varianti LTR 1713 (90), samuti arutlust esimese variandi üle teksti sees).

Ó Súilleabháin, Seán \& Christiansen, Reidar Thoralf 1967. The Types of The Irish Folktale. Folklore Fellows' Communications 188. Helsinki: Suomalainen Tiedeakatemia. Nr 704. Üks tekst (Ireland's Own (20.07.1946) 22; saatnud Nora O’Brien Tipperaryst laste kogumisvõistluse osana). Kui mõned väiksed detailid välja arvata, on tegemist H. C. Anderseni versiooni tõlkega, kuid ühe herne asemel on seal kolm hernest (nagu Grimmide tekstiski) ja kokkuvõttev osa (Ja hernes paigutati muuseumisse [---]) puudub hoopis (vt ka hollandi teksti). Tahaksin tänada Patricia Lysaghti Dublinist, kes minu uurimuse tarbeks selle teksti transkribeeris.

Jurjen van der Kooi arhiiv (Groningen). Nr 704. Üks tekst (Provinciale Groninger A. Hazelhoff's Almanak voor het jaar 1870. Groningen [1869], lk [123-125]). See anonüümne almanahhijutt pealkirjaga Een sprookje van den deenschen dichter Andersen järgib lähedalt H. C. Anderseni versiooni, kuigi ta ei esinda puhtakujulist tõlget (nagu iiri tekstis, on siingi ühe asemel kolm hernest ja kokkuvõttev osa puudub). Tahaksin tänada Jurjen van der Kooi't selle teksti koopia saatmise eest.

González Sanz, Carlos 1996. Catálogo tipológico de cuentos folklóricos aragoneses. Artularios 1. Zaragoza: Instituto Aragones de Antropologia. Nr 704. Üks avaldamata lugu, mida siinkirjutaja ei ole näinud, aga kirjelduse järgi otsustades võib see olla laenatud H. C. Andersenilt.

Camarena Laucirica, Julio \& Chevalier, Maxime 1995. Catálogo tipológico del cuento folklórico español: Cuentos maravillosos. Biblioteca románica hispánica IV. Textos 24. Madrid: Gredos. Nr 704.

Neli teksti. Kaks kolmest katalaani tekstist esindavad naeruväärse ülitundlikkuse motiivi töötlust (vrd Amades 1950: nr 393; Alcover 1953: $49 \mathrm{jj}$ ), üks neist on AT 402 versioon (Hiir [kass, konn, jne] pruudiks), mis sisaldab peigmehe proovilepanekut (vrd Amades 1950: 127). Sephardi juutide muinasjutt Marokost on lugu meessoost herneotsijast (vrd Larrea Palacín 1952: nr 58). 


\section{Christine Shojaei Kawan}

Jason, Heda 1964-1965. Types of Jewish-Oriental Oral Tales. Fabula 7, lk 115-224. Nr 704. Kolm teksti. Tuneesia jutt (IFA 2508) on variant meessoost herneotsija loost (vrd Larrea Palacín 1952: nr 58); pärsia (IFA 4099) ja afgaani (IFA 2483) jutud on võrsunud Seitsme targa raamatust ühes läbinägelikkuskatse traditsiooniga (vrd üleskirjutustega nr 4099 ja nr 2483 Iisraeli Rahvaluulearhiivis). Tänan Edna Hechali Haifast, kes saatis mulle Iisraeli Rahvaluulearhiivist need tekstid (tõlked tegi Katrin Nele Jansen Göttingenist).

Jason, Heda 1989. Types of Indic Oral Tales. Folklore Fellows' Communications 242. Helsingi: Suomalainen Tiedeakatemia. Nr 704. Kaks teksti. Esimene neist (Andra Pradeshilt) sarnaneb meessoost herneotsija lugudega ainult selle poolest, et loo kangelane saab jõukaks tühise juhuse läbi - see on pigem paralleel laialtlevinud lugudele sellest, kuidas inimesed sepitsevad jõukaks saamise plaane (AT 1430: Mees ja naine ehitavad õhulosse). Kuid selles mõttes erandlikus india loos lähevad arvestused täide. Teine (Kashmirist pärit) tekst pole minu arvates samuti seotud tüübiga AT 704 (naine arvab, et koletis rebis talt magamise ajal kõrvarõnga ära, kuid korravalvur leiab selle voodikatte lõime küljest rippumast). Tänan Heda Jasonit Jeruusalemmast, kes mulle need tekstid saatis.

Thompson, Stith \& Balys, Jonas 1958. The Oral Tales of India. Indiana University Publications. Folklore Series 10. Bloomington: Indiana University Press. H 41.1. Üks tekst.

Lőrincz, László 1979. Mongolische Märchentypen. Asiatische Forschungen 61. Wiesbaden: Harrassowitz. Nr 704A*. Üks tekst, mis jutustab kitsekarjusest, kes tahab abielluda khaani tütrega. Ta asetab riisitera lina alla ja teeskleb selle leidmist, et tõestada oma suursugust päritolu.

Ting, Nai-tung 1978. A type index of Chinese folktales: In the oral tradition and major works of non-religious classical literature. Folklore Fellows' Communications 223. Helsinki: Suomalainen Tiedeakatemia. Nr 704. Üks tekst (kaks trükist), mis käsitleb naistele omast ülitundlikkust. 


\section{Lisa 5. Printsess herneteral (vennad Grimmid)}

Kunagi elasid ühel vaiksel maal kuningas ja kuninganna, kellel oli poeg, prints Toringarde. Rahvas armastas kuningaperet, kuid prints ei olnud õnnelik.

"Ma olen nii kurb," ütles prints vanematele. "Ma tahaksin abielluda, kuid ei leia endale õiget pruuti."

"Seda asja annab hõlpsasti korraldada," lohutas kuningas. "Ühepäevase ratsasõidu kaugusel meie lossist elab tervelt neliteist printsessi.”

"Ma olen kõiki neid tüdrukuid näinud," vaidles Toringarde vastu, "aga nad ei ole õiged printsessid. Neil ei ole seda erilist kuninglikkust, mida ma oma naise juures tahaksin näha."

Sellised märkused ajasid kuninganna nutma, sest ta tahtis, et poeg oleks õnnelik, abielus ja kingiks talle lapselapse.

"Ma tean, mida teha," otsustas kuningas. "Ma saadan välja kirjaliku teate, et sa tahad abielluda ja et kõik tõelised printsessid võivad tulla ja sinuga silmast silma kohtuda. Nii kohtud sa sobivate neidudega kõigist maadest."

Ja nii laskis kuningas koostada, trükkida ja igale poole välja panna teate, et tema poeg otsib tõelist printsessi. Järgmise paari nädala jooksul tuli palju printsesse lossi prints Toringardega kohtuma.

Kuid keegi neist ei pannud printsi südant kiiremini tuksuma. Kellelgi neist ei olnud seda erilist kuninglikkust, mida prints otsis. See muutis printsi veel kurvemaks, ent kuninganna ei kaotanud lootust.

“Küll sa näed, mu poeg,” ütles ta, "just siis, kui asi tundub täiesti võimatu olevat, juhtub midagi. See võib olla kohe siinsamas, ukse taga. Tuleb ainult osata näha seda, mida otsid.”

Printsile tundus, et ema pü̈̈ab teda lihtsalt lohutada. Ta ei uskunud ema sõnu. Kui selline printsess, kes talle sobinuks, oleks olemas, võiks ta nü̈̈dseks juba olla lossis käinud.

Kui prints kurvalt oma toas istus ja elu üle järele mõtles, kuulis ta väljast valju tuule ulgumist. Ta hüppas püsti ja jooksis suurde eesruumi.

Sinna olid kogunenud ka kuningas, kuninganna ja kõik teenijad. "Mis lahti on?" küsis prints Toringarde.

"Väljas on kohutav torm,"vastas kuningas. "Tuul, rahe, äike. Meie kuningriigis pole veel kunagi midagi seesugust nähtud ega kuuldud."

Samal hetkel kõlas eesuksele vali koputus. "Tuul püüab eesust sisse lüüa!” hü̈̈dis üks teener.

"Ei," ütles Toringarde ja asetas käe mõõgale. "See ei ole tuul. See on inimese käsi, mis uksele koputab. Ma lähen vaatan, kes seal on."

Kõik vaatasid, kuidas prints Toringarde ukse juurde astus. Ta võis olla küll üksik ja ta süda võis olla armastuse puudumise pärast 


\section{Christine Shojaei Kawan}

haige, kuid ta oli ikkagi julge ja vapper prints. Mõõga tupest välja tõmmanud, avas ta ettevaatlikult eesukse.

Lävel seisis üleni veest tilkuv noor neiu. Prints Toringarde silmitses teda. "Kes sa oled?" küsis ta.

"Ma olen printsess Annasara," vastas neiu, "ja kui te mind sisse ei lase, upun ma siinsamas selles vihmavalingus."

Prints tõmbus kõrvale ja printsess astus sisse. "Ma olin parajasti reisil tagasi oma kuningriiki, kui puhkes see kohutav torm," selgitas printsess, kui teda tutvustati kuningale, kuningannale ja kogu oukonnale.

Siis jutustas ta, kuidas oli selle metsiku maru kätte jäänud. Rääkides hakkasid ta juuksed ja riided juba kuivama. Prints Toringarde nägi, et printsess on väga ilus. Tema hääl oli meeldiv ja siiras ning tema silmad nii sügavad, et prints polnud seesuguseid eales näinud. See oli kindlasti seesama neiu, kes ema sõnul pidi teda kohe siinsamas, ukse taga ootama.

"Mitte nii kiiresti, mu poeg," ütles kuninganna, kui poeg sosinal oma tunnetest emale rääkis. "Enne tuleb teha kindlaks, kas see on tõepoolest ehtne printsess ja veel selline, kes suudaks sind terveks eluajaks õnnelikuks teha."

"Kuidas me seda teeme?" küsis prints emalt.

“Jäta kõik minu hooleks," lausus ema. Siis pöördus kuninganna printsess Annasara poole. "Kas ma tohin sind su magamistuppa juhatada, kullake?” küsis ta. Väljas möllas torm endise jõuga ning printsessil tuli jääda ööseks lossi.

"See oleks mulle suur au, Teie Hiilgus," vastas printsess kniksu tehes.

"Kena. Ma lähen vaatan, kas kõik ettevalmistused on tehtud. Ma kutsun sind, kui tuba on valmis.” Kuninganna läks trepist üles magamistuppa.

Ta võttis taskust tillukese rohelise herne ja torkas selle voodisse madratsi alla. Siis andis ta teenritele käsu panna voodisse veel kakskümmend madratsit, nii et ülemine madrats puudutas peaaegu lage.

“Printsess Annasara, sinu voodi on valmis!” teatas kuninganna seejärel.

Printsess tõusis toolilt. "Võib-olla näeme hommikul," ütles ta printsile.

"Ma loodan seda väga,”vastas prints. Seejärel läks printsess trepist üles.

Ta astus oma magamistuppa ja lausa ahhetas tohutut madratsikuhja nähes.

Kuninganna naeratas. "Ma tahtsin, et sul oleks nii mugav kui võimalik," selgitas ta. 
Christine Shojaei Kawan

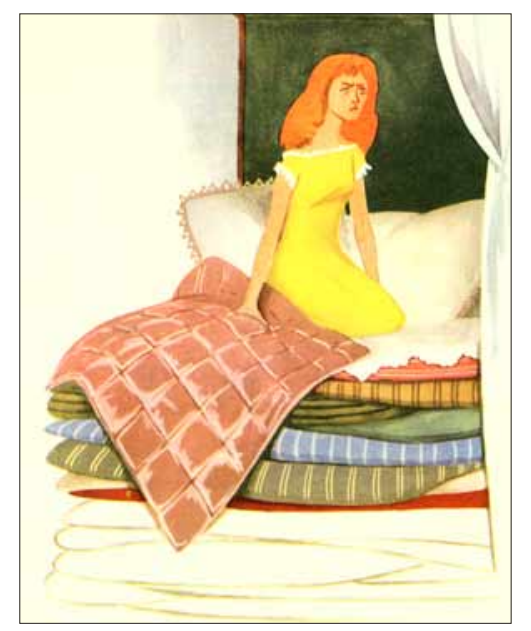

Joonis 4. Maret Kernumehe illustratsioon Hans Christian Anderseni muinasjutule Printsess hernel. Raamat Kaks muinasjuttu, Tallinn 1964.

Printsess tänas kuningannat ning ronis üles, kuni jõudis ülemise madratsini. Ta tõmbas endale teki peale ja sulges silmad.

"Meeldivaid unenägusid," ütles kuninganna. "Pärast nii rasket teekonda oled sa kindlasti väsinud.” Kuninganna sulges enda järel ukse ja läks tagasi alumisele korrusele.

Hommikuks oli torm raugenud. Päike tõusis kaugete mägede kohale. Kuninganna tõusis ja läks printsess Annasara magamistuppa.

Printsess kõndis toas edasi-tagasi ja hõõrus käega selga.

"Mu kullake, mis lahti on?" päsis kuninganna. "Ma arvasin, et sa magad veel."

"Ma ei tahaks kurta, aga ma ei saanud terve öö sõbagi silmale," ütles printsess.

“Tõepoolest?" imestas kuninganna. "Aga miks ometi?"

“Ärge solvuge, Teie Hiilgus," ütles printsess, "aga see oli kõige kõvem madrats, millel ma elus olen maganud. Mu selg hakkas sellest koledasti valutama."

Kuninganna naeratas. "Sa oled tõeline printsess!" hü̈̈atas ta rõõmsalt.

"Muidugi olen," imestas printsess. "Ma ütlesin seda teile juba eile ôhtul."

"Aga sa pidid proovi läbi tegema ning tegid seda edukalt," ütles kuninganna. 


\section{Christine Shojaei Kawan}

“Millise proovi?” ei taibanud printsess Annasara ja hõorrus selga. Nü̈d astus tuppa ka prints Toringarde. "Mis on juhtunud?” küsis ta.

"Sinu armastatu on tõeline printsess," ütles kuninganna. "Eile õhtul panin ma tema voodi põhja tillukese rohelise herne. Siis katsin ma selle kahekümne madratsiga. Ainult tõeline ja õrn printsess võiks herne pärast ebamugavust tunda."

"Siis oled sa minu tõeline printsess," ütles Toringarde ja võttis Annasara käe oma pihku. "Me kohtusime tormi tõttu, kuid meie eelseisev elu on puhas rõom.”

Printsil oli õigus. Kuninganna laskis saata printsessi tuppa kalliskividega kaunistatud kuninglikud rõivad. Toringarde ja Annasara pulmad olid kuu aja pärast ning kõik on tänagi ühel meelel, et nad elasid kaua-kaua õnnelikult (Grimmid 2000: 184-195).

\section{Kommentaarid}

${ }^{1}$ Originaalteksti vt lisast 1 (artikli ingliskeelses originaalvariandis kasutatud varianti vt Andersen 1980: 11 jj). Suurem osa, kui mitte kõik jututüübi AT 704 (Printsess herneteral) variandid pärinevad H. C. Anderseni versioonist, ent regionaalsed jututüübiindeksid ja muinasjutukogumikud viitavad ka teist laadi lugudele erakordsest tundlikkusest või taibukusest (Mot F 647 - F 647.12; vrd ka AT 655 (Taibukad vennad), AT 655A (Eksinud kaamel ja nutikad järeldused) ja AT 545A (Kassi loss)) motiivid ja jutuvariandid, milles esineb muinasjutus Printsess herneteral kirjeldatud voodikatse (vt lisa 4).

${ }^{2}$ Hans Christian Anderseni vastav jutt pealkirjaga Printsess hernel, ka Printsess herneteral (Jung 1994: 19-29; 2000: 19-29 jm), Printsess herneteral eestindustest vaata lähemalt Eerik Tederi (1996) järelsõnast taani muinasjutumeistri eestikeelsele kogumikule Lumikelluke (toim).

${ }^{3} \mathrm{~S}$. Thompson ühendab ülitundlikkuse motiivid ja motiivid erilise taibukuse kohta (Mot F 647.1, F 647.1.1, F 647.5-F 647.5.3, F 647.9.2), niisamuti nagu erinevad jutud on pandud kokku tüübinumbri AT 704 (vt lisa 4) alla.

${ }^{4}$ Ainuke loogika seisukohalt rahuldav versioon on Dīhnawarī ( $\operatorname{srn} 895$ ) oma: kuningas abiellub reetliku tütarlapsega, et formaalselt täita oma lubadus, ja laseb ta seejärel kohe tappa (vrd Christensen 1936: 247).

${ }^{5}$ Peale kahe versiooni mainimise, kus kangelanna isa hukatakse pärast linna vallutamist, ei tule A. Christenseni uurimusest (Christensen 1936: 247) välja, kas hukkajateks olid linna sissetunginud sõdurid või tehti seda kuninga selgesõnalisel korraldusel, seda enam, et A. Christensen ei ole käsitlenud küsimust, kas kangelanna oli teadlik, et tema isa peab surema. 


\section{Christine Shojaei Kawan}

${ }^{6}$ Vrd A. Christensen (1936: 249): le charme rompu (eesti k 'petlik võlu').

7 Üks sarnaneb ülalmainitud looga, kuid seal puudub abielumotiiv (Alcover 1953: $49 \mathrm{jj}$ ), teises (Alcover 1956: 18-26), raskesti liigitatavas jutus pruudi proovilepanekust, mida võib kirjeldada kui jututüübi AT 313 naissoost kangelasega paralleeli (Tüdruk abistajaks kangelase lennul), tabab ebaõnn (haldja)kuninganna Morgana vana ema (Printsessi herneteral tuletab eriti meelde tema teine äpardus: kuninganna ema murrab ribi, sest ta voodi 13 madratsi vahel on juuksekarv). Samu motiive vt ka Christian Schnelleri kogutud loos (Schneller 1867), millest tuleb juttu käesoleva kirjutise lõpus.

${ }^{8}$ Antiikkirjanduse klassikaline teatmeteos Paulys Real-Encyclopädie der classischen Altertumswissenschaft (1931-) sisaldab mh ulatuslikku artiklit Sybarisest (ibid.: veerud 1005-1010, vrd veerud 1002-1005), kuid seal mainitakse linna rikkust, küllust ja dekadentsi ainult möödaminnes (veerud 1005, 1006).

9 Vrd Webster's Third New International Dictionary of the English Language 3. (Chicago 1981). Märksõnade sybarite ja sybaritic sünonüümiks on antud sensuous 'meeleline' (mitte: [üli]tundlik); vt ka Großer Duden, märksõnad Sybarit, sybaritisch; Le Petit Robert, märksõna sybarite; Pons Gran Diccionario de la lengua española, märksõna sibarita; Dizionario Sansoni ItalianoTedesco, märksõnad sibarita, sibaritico. Vaid mõni üksik nendest sõnastikest vihjab teisejärguliselt ka dekadentlusele (Verweichlichung, mollesse).

${ }^{10}$ Helmut Hoffmanni arvates on loo välja mõelnud anonüümne autor pärast aastat 68 pKr (Hoffmann 1992: 736). Kui see vastab tõele, peaks teos pärinema enam-vähem Seneca kaasajast.

${ }^{11}$ Lühem versioon leidub Śivadāsa adaptatsioonina (Uhle 1924: 63 (nr 10); vrd ka Ruben 1964: 142 jj (nr 11); Oesterley 1873 (nr 10); Behadur KaleeKrishen 1834 (nr 10); Barker 1855 (nr 10)).

12 Vetālad on india usundi kalmistutel elavad kurjad vaimud (deemonid), kes lõbustavad end laipadesse pugemisega (toim).

${ }^{13}$ Kuigi on tõenäoline, et ülitundlikkuse motiiv pärineb Idamaadest, kuna seal on see hästi tuntud ja esineb väga erinevais variantides (vrd Schick 1934: 144).

${ }^{14}$ Klassikaline roosilehemotiiv ja sellest veel tuntum ebamugava magamisaseme motiiv (antud juhul põhjustatud kortsust voodilinas) on tuntud ka katalaani traditsioonis: kolmas naine teeskleb, et kolm-neli valele poole kammitud juuksekarva juukselahus surusid ta kaela nädalateks kõveraks, neljas väidab, et roojamise ajal lõhkes tal istmikus veresoon.

15 Võrdlev-ajaloolise suuna esindajatel on kalduvus sellistest erinevustest mööda vaadata. Nad pigem püüavad loetleda nii palju sarnaseid 


\section{Christine Shojaei Kawan}

motiive kui võimalik (vrd Bolte \& Polívka 1918: 238 jj, 332; Fischer \& Bolte 1895: 217; Christensen 1906: 171-173; Liungman 1961: 152 jj).

${ }^{16}$ Kalamotiiv puudub, naerab hoopis linnupraad (Tuti-Nameh - Rosen [1923]: 246-254). Rohkem variante on välja toodud Mahroo Hatamil (Hatami 1977: nr 35 (Kahekümnes öö)).

17 Vahel naerab linnupraad söögilaual või ööbik puu otsas (vrd ka Schick 1934: 277).

18 Tänan Jörg Bäckerit Gummersbachist kommentaari eest Tingi kataloogi kohta ja konsulteerimise eest paari hiina jutukogumiku asjus, mis on ilmunud pärast 1980. aastat, kuid kus siiski teisi seda tüüpi lugusid ei leidu.

${ }^{19}$ Vetāla kahekümne viie jutu viie redaktsioon ning Kathāratnākara (eesti $\mathrm{k}$ Jutustuste jõgede ookean) ja ühe india rahvajutu variandid.

${ }^{20}$ Koomiline kirjeldus mehe kogemusest, kes oli nõudlik voodite suhtes, leidub Kathāsaritsāgaras (Tawney 1884: 273).

${ }^{21}$ Ingliskeelse termini serendipity, mille abil märgitakse detektiivide induktiivset meetodit või juhuslikku terasust, on võtnud kasutusele Horace Walpole, ja see on tuletatud Christoforo Armeno pealkirjast Peregrinaggio di tre giovani figliuoli del re di Serendippo (vrd Piemontese 1995: 334 jj).

${ }^{22}$ Maitsemeele ülitundlikkus, nagu seda kirjeldab Motif-Indexi koostaja kui erakordset maitsemeelt - naine tunneb kü̈̈slaugu maitset kastmes, mis on tehtud uhmrikausis, kus on varem olnud küüslauk (Thompson 1956: Mot. F 647.1.1), - ei nõua iseenesest erilist maitsepeenust.

${ }^{23}$ Idee autor Frank Elstner. Esimene saade oli ekraanil 14. veebruaril 1981.

${ }^{24}$ Kaks viimatinimetatud kihlvedu korraldati 122 . saates (26. veebruaril 2000), esimese kihlveo kuupäeva ei mäleta.

${ }^{25}$ 128. saade (17. veebruaril 2001).

${ }^{26}$ Araablaste jälgede ajamise kohta vt J. Schick (1934: 316 jj; 1938: 425) ja K. Ranke (1979: 883).

${ }^{27}$ Nii selle kui teise jutu (mida mul pole õnnestunud näha) on ära toonud S. Thompson ja J. Balys (Thomson \& Balys 1958: F 647.9.1).

28 Tsiteeritud Penzeri (Penzer 1923: 294) järgi (Ellis 1848: 412 jj). Olen leidnud antud episoodi järgmistest versioonidest: Polo de Beaulieu (1991: 377), Misrahi (1933: 13 jj), Keller (1841: 41), Loiseleur-Deslongchamps (1838: 4 jj) ja Rajna (1880: 12). Vt ka Schick (1938: 447 jj).

${ }^{29}$ Iisraeli rahvaluulearhiiv, $\mathrm{nr} 4099$, jutustanud Yonisian Ovadja, sündinud 18. mail 1962 Iraanis Kermanshahis, emigreerunud Iisraeli 1952 [üks 
kahest kuupäevast on kindlasti vale - autori märkus], Ashkaloni vildivabriku töödejuhataja; lindistamisaasta puudub.

${ }^{30}$ USA 1976, re •issöör Robert Moore.

${ }^{31}$ Iisraeli rahvaluulearhiiv, nr 2483. Jutustanud Afganistanist pärit immigrant Qoret Zebulon 1960. aastal.

32 Olen erakordselt tänulik Dáithí Ó hÓgáinile Dublinist informatsiooni eest Seitsme targa lugude episoodide teisenditest Iirimaal ja Bo Almqvisti (2003) artikli Arastotail ar an mBlascaod kättejuhatamise eest, mis oli siis just ilmumas Gearóid Mac Eoinile pühendatud artiklikogumikus ja käsitleb Aristotelest puudutavat rahvapärimust Blasketi saarel (Iirimaa, Lääne-Kerry). Lugu on jäädvustatud: University College Dublin, Department of Irish Folklore, Irish Folklore Collection Manuscripts nr 913, lk 196 (kogunud Seán Ó Cróinín Donncha Ó Donnabháinilt Clonakiltyst 1943. aastal) ja nr 1492, lk 271-273, kirja pannud Micheál Ó Gaoithín (kuulsa jutuvestja Peig Sayersi poeg) Dunquinis, Kerry maakonnas; Irish Folklore Collection Almquist Tape 1967: 1 ja 1974: 6 (mõlemad on Bo Almqvist lindistanud Micháil Ó Gaoithínilt).

${ }^{33}$ H. C. Andersen polnud siiski folkloorikoguja nagu vennad Grimmid, vaid poeet, kes oma töö üle uhkust tundis, vrd Hovmanni kommentaari Anderseni muinasjuttude kommenteeritud kogumikus (Eventyr 1990b: 25): og da han ellers er serlig øm om at fremheve sine originale eventyr, må hans ord stå til troende (ja kuna ta pidevalt rõhutab oma lugude algupära, võib tema sõnu usaldada). (Kõik tõlked taani keelest selles artiklis on tehtud Berit Lusebrinki (Göttingen) tõlgete kaudu.)

${ }^{34} \mathrm{Mis}$ puutub muinasjuttu osavatest vendadest (AT 655/655A), siis J. Schicki andmetel (Schick 1934; 1938) on variandid, kus esineb voodiekspert, üsna piiratud ega ole imbunud euroopa kirjandusse. 1001 öö kolme asjatundjaloo ühes näites ollakse asjatundja ainult leiva, liha ja inimeste ning kahes teises juveelide, hobuste ja inimeste alal (Schick 1934: 384440). Euroopa allikatest, mida H. C. Anderseni isa võis tunda, nimetagem Christoforo Armeno Peregrinaggiot, kus esineb asjatundmist ainult liha, veini ja inimeste alal (Schick 1938: 346-359; Fischer \& Bolte 1895: 2232 ), samuti selle mugandusi: Mailly versioon vastab Peregrinaggiole, Gueulettel on ainult liha- ja veinikatse; Voltaire'i Zadig sisaldab ainuüksi jäljeajamise episoodi, mis tavajuhtudel üksnes eelneb igasugustele muudele katsumistele (vrd Schick 1938: 413-425).

${ }^{35} \mathrm{Nr} 545 \mathrm{~B}$ variant $34=\mathrm{nr} 704$ variant 3.

36492 (soome variant AT 545) ja 500 (soome variant AT 704). Mitmed sajast soome Kassi lossi jutu variandist sisaldavad voodikatse episoodi. Tänan Merili Metsvahit Tartust nende kommentaaride tõlkimise eest. 


\section{Christine Shojaei Kawan}

${ }^{37}$ Lisavariandid: Schier (1971: nr 6), Simonsuuri \& Rausmaa (1968: nr 53), Rausmaa (1988: nr 85). Võlgnen tänu tõlke eest Susanna Sallinenile Turust.

${ }^{38}$ Mainitud koos G. Christenseni (1906: $170 \mathrm{jj}$ ) rootsi variandiga.

${ }^{39}$ Warren E. Roberts (1964: 43) viitab meessoost kangelasega norra Kassi lossi loole, mida mul siiski ei õnnestunud $\varnothing$. Hodne kataloogi järgi identifitseerida. AT 402 katalaani variandis (Hiir (kass, konn jt) pruudiks) pannakse peigmehe proovilepanekuks tema voodisse läätsetera (Amades 1950: $\mathrm{nr}$ 127). Vt ka ülalmainitud himaalaja jutte (Lorimer 1935; Minajev 1876-1877) ja L. Lőrinczi (1979) mongoolia muinasjututüüpi nr 704A* (vrd lisa 4).

${ }^{40}$ Uurimuse ajaloo täielikumaks kirjelduseks ja arutluseks vrd KöhlerZülchi artiklit AT 545B kohta (Köhler-Zülch 1993: 1076 jj) ja märkust 31.

${ }^{41}$ Variantide näited: Bolhar (1974: 76-82), Larrea Palacín (1952: nr 52), Iisraeli rahvaluulearhiiv, nr 2508, jutustanud Tuneesia päritolu immigrant Iisraelis Masuda Mazuz 1960. aastal.

${ }^{42}$ W. Scherf (1995: 840) nimetab seda groteskseks looks.

${ }^{43}$ Mainitud variantide hulgas on neli muud juttu, mis sisaldavad voodikatse episoodi. Kassi lossi varaseim variant aastast 1830 (Sundbladi Gammeldags seder och bruk), mis on kirja pandud enne H. C. Anderseni loo kirjutamist, polnud mulle kahjuks kättesaadav. Rootsi Kassi lossi juttude teemal on arutlenud G. Christensen (1906: 169-171).

${ }^{44} \mathrm{H}$. Brix kirjutab, et H. C. Anderseni allikaks on jutt, mida Ludwig Tieck on töödelnud loos Saabastega kass (saksa k Der gestiefelte Kater), mille toel ta viitab jututüübile AT 545A/B. Kuigi samas kontekstis väidab H. Brix ka, et jutt ei esine taani traditsioonis, küll aga on see tuntud Rootsis, tundub see kahemõtteline lõik olevat viinud ekslikule eeldusele, et L. Tiecki näidend oli allikaks H. C. Anderseni Printsessile herneteral vrd Flemming Hovmanni kommentaari H. C. Anderseni juttudele (Eventyr 1990b: 25).

${ }^{45}$ Tänan Jean-Michel Adamit käsikirja saatmise eest.

46 Anderseni juttude tõlkimise probleemide kohta vt V. H. Pedersen (1993: 197, 203); J. W. Glyn (1993: 211 jj - arutelu jutu Printsess herneteral ingliskeelsete tõlgete teemal; sõnade rigtig, virkelig ja rigtig Historie vastete asjus); vt ka L. L. Albertsen (1970), mida siinkirjutaja ei ole veel näinud.

${ }^{47}$ Kommentaari vt Grimm (1984: 541), teksti kohta vt ka lisa 2.

${ }^{48}$ Eesti keeles on avaldatud mugandusi (pealkirjaga Printsess herneteral (nt Grimmid 2000, millest printsessi julge käitumise motiiv tulla end printsile naiseks pakkuma on välja jäetud), vt ka lisa 5 ja vrd lisa 2 (tõlk). 


\section{Christine Shojaei Kawan}

${ }^{49}$ Kiri 26. juulist 1844: [---] og Damerne vilde slet ikke tro mig; thi naturligviis naar jeg nu overvældes med Hyldest og fortælles at jeg er den bekjendteste Digter $i$ Norden, svarer jeg, det er ikke saa: Grimm har jo ikke engang hørt mit Navn; naragtigt er det imidlertid, da han i sin nye Samling af æote Folke-Eventyr, skal have optaget eet af mine originale, rigtig nok i den Tro at det tilhørte kun de Danske. ([---] ja daamid ei usuks mind, sest loomulikult, kui kiitus mind aupaistena ümbritseb ja kui mind kutsutakse kõige tuntumaks poeediks Põhjamaades, siis ma võin vastata, et minuga ei ole see mitte nõnda: Grimm pole mu nimegi kuulnud. Vahepeal on see muutunud naeruväärseks, sest oma uude rahvajutukogumikku on ta kuuldavasti sisse pannud minu omaloomingut, uskudes, et see on algupärane taani jutt). Jääb selgusetuks, miks H. C. Andersen arvas, et vennad Grimmid tahtsid panna taani jutu saksa jutukogumikku.

${ }^{50}$ Oma kirjas Karl Simrockile 9. veebruarist 1852 teatab Wilhelm Grimm üksnes, et ühe jutu asendamise põhjusi selgitatakse järgmises väljaandes (kolmandas köites?): Miks ma ühe muinasjutu viimases väljaandes teisega asendasin, kavatsen selgitada järgmine kord, kui samal viisil toimin. Ammu käsil oleva kolmanda köite tahaksin meeleldi uuesti trükkida lasta: seal on palju täiendusi ja mõndagi tuleb ümber töötada (Ottendorff-Simrock 1966: 71). Teadaolevalt ei ole midagi sellesisulist avaldatud.

51 Tekst on kirjas lisas 3. Sama loo suulise variandi üleskirjutus LTR 1713 (90) leidub Leedu rahvaluulearhiivis (Vilniuses Leedu Kirjanduse ja Rahvaluule Instituudis) ja selle on jutustanud 10. augustil 1938 Salakases Ida-Leedus naisinformant, kes oli lugu kuulnud oma nooruses. Kõnealuses variandis ei leidu abielusoovi motiivi ega ole üldse juttu abielust; noormees, kes omal algatusel printsessi proovile paneb, on mõisniku poeg.

52 Nii arvab A. Christensen (1936: 257). Ta julgeb isegi oletada, et H. C. Andersen võis kuulda lugu mõne Taani immigreerunud saksa perekonna liikmelt. Ent juhul, kui sellised lood levisid juba enne H. C. Anderseni, miks siis ainult Saksamaal? Pealegi eelneb H. C. Anderseni versioon Grimmide tekstile ja kui hernekatse motiiv on algselt idamaist päritolu, peaks selliseid lugusid leiduma teisteski maades.

${ }_{53}$ Taani k: Paa min Maade har jeg fortalt dem, tilladt mig enhver Forandring, jeg fandt passende, ladet Phantasien opfriske de i Billederne afblegede Farver.

54 "Printsessi herneteral" [---] kuulsin enne kooliminekut, mil mulle seda (koos viie muu jutuga) kui muinasjuttu jutustati [---],ja olen loo nü̈̈d omal viisil siin edasi andnud (Andersen 1847: V jj). H. C. Andersen mainib, et kolm lugu on inspireeritud kirjanduslikest allikatest ja 30 on tema omalooming.

${ }^{55}$ On iseloomulik, et 19. sajandi folkloristid nimetasid end otsesõnu või kaudselt kirjutavateks jutustajateks; vrd Köhler-Zülch \& Shojaei Kawan (1990: 255) ja Köhler-Zülch (1999). Vennad Grimmid näiteks väidavad, et 


\section{Christine Shojaei Kawan}

on truult säilitanud kõik sisulised detailid, aga lisavad, et väljendusviis ja detailide viimistlus on muidugi enamalt jaolt nende omalooming: Wir haben nämlich aus eigenen Mitteln nichts hinzugesetzt, keinen Umstand und Zug der Sage selbst verschönert, sondern ihren Inhalt so wiedergegeben, wie wir ihn empfangen hatten; daß der Ausdruck und die Ausführung des Einzelnen großenteils von uns herrührt, versteht sich von selbst [---] (Grimm 1843a: XXI).

${ }^{56}$ [---] habe ich heftige Liebe zu ihm empfunden [---], in der Absicht, seine Gemahlin zu werden.

57 [---] das Glück steht oft vor der Türe, man braucht sie nur aufzumachen; so blüht hier dein Weizen nicht.

${ }^{58}$ Vrd Aarets Historie (1852; Evertyr 1964: 217-224; eesti k Aasta ajalugu (Andersen 1987: 328-333)), Vinden fortæller om Valdemar Daae og hans Døttre (1859; Eventyr 1965: 103-112; eesti k Tuul jutustab Valdemar Daaest ja tema tütardest (Andersen 1996: 49-59)), Gaardhanen og Veirhanen (1860; Eventyr 1965: 159-161; eesti k Ôukukk ja tuulelipukukk (Andersen 1996: 100-102)); Stormen flytter Skilt (1865; Eventyr 1966: 220-223; eesti k Torm viib sildid minema (Andersen 1996: 278-281)).

${ }^{59}$ Meenutagem, et G. Christenseni (1906: 169) teatel tuleb ka Sundbladi 1830. aasta Kassi lossis tütarlaps vihmasel õhtul lossi juurde.

${ }^{60}$ Herneste lugemise kohta vt A. Christensen (1936: 257).

${ }^{61}$ Ob er daran wol gethan? Leider weiss es die Erzählerin nicht, denn es ist ihr der Faden ausgegangen (eesti k: Kas ta talitas seejuures hästi? Kahjuks jutustaja seda ei tea, sest siin tema jutulõng katkeb).

\section{Kirjandus}

Aarne, Antti \& Thompson, Stith 1961. The Types of the Folktale: A classification and bibliography. 2., parand tr. Folklore Fellows' Communcations 184. Helsinki: Suomalainen Tiedeakatemia.

Adam, Jean-Michel 2000. Textualité et transtextualité d'un conte d'Andersen: "La Princesse sur le petit pois". Ette kantud Lausanne'i ülikooli sotsiaal-ja pedagoogikateaduste instituudi korraldatud konverentsil Contes et théorie du récit 16.-17. oktoobril 2000.

Afzalov \& Hussainova 1963 = Афзалов, Мансур \& Хусаинова, Зубаида $e t$ $a l$. (toim). Узбекские народные сказки в двух томах 2. Ташкент.

Albertsen, Leif Ludwig 1970. Die Deutschen und ihr Märchendichter Andersen: Bemerkungen zur Übersetzungsproblematik an Hand der "Prin- 
zessin auf der Erbse". Niels Oxenvad \& Helge Topsøe-Jensen (toim). Anderseniana 3 I: 1. Årbog: H. C. Andersens Hus, lk 71-87.

Alcover, Antoni Maria 1953. Aplec de Rondaies Mallorquines d'en Jordi des Racó VI. Palma de Mallorca: Moll.

Alcover, Antoni Maria 1956. Aplec de Rondaies Mallorquines d'en Jordi des Racó XI. Palma de Mallorca: Moll.

Almqvist, Bo 2003. Arastotail ar an mBlascaod. Dónall Ó Baoill \& Donncha Ó Haodha (toim). Féilscríbhinn Ghearóid Mhic Eoin. Dublin: Four Courts Press.

Amades, Joan 1950. Folklore de Catalunya: Rondallística. Rondalles, tradicions, llegendes. Biblioteca Perenne 13. Barcelona: Editorial Selecta.

Andersen, Hans Christian 1847. Gesammelte Märchen III. Leipzig: Verlag von Carl B. Lorck.

Andersen, Hans Christian 1850. Sämmtliche Märchen. Leipzig: Teubner (kasutatud kordustrükk: Andersen, Hans Christian 1983. Sämmtliche Märchen. Die bibliophilen Taschenbücher 89. Dortmund: Harenberg).

Andersen, Hans Christian 1980. Tales and Stories. Seattle \& London: University of Washington Press.

Andersen, Hans Christian 1987. Väike merineitsi: Muinasjutud ja lood. Tallinn: Eesti Raamat.

Andersen, Hans Christian 1996. Lumikelluke: Muinasjutud ja lood. Tallinn: Eesti Raamat.

Arājs, Kārlis \& Medne, Alma 1977. Latviešu pasaku tipu rādītājs = Указатель типов латышских народных сказок = The types of the Latvian folktales. Rīga: Zinātne.

Barker, Burckhardt W. (tõlk ja komment) 1855. The Baitál Pachísí or Twentyfive Tales of a Demon. A new edition of the Hindítext, with each word expressed in the Hindústání character immediately under the corresponding word in the Nágarí; and with a perfectly literal English interlinear translation, accompanied by a free translation in English [---] and explanatory notes. Hertford: Stephen Austin.

Basanavičius, Jonas 1993. Lietuviškos pasakos ivairios I. Vilnius: Vaga.

Behadur Kalee-Krishen, Rajah (tõlk) 1834. Bytal-Puchisi: Or The Twentyfive Tales of Byal. Calcutta: Sobha Bazar Press.

Bolhar, Alojzij 1974. Slovenske narodne pravljice. Ljubljana: Mladinska knjiga.

Bolte, Johannes \& Polívka, Georg 1918. Anmerkungen zu den Kinder- $u$. Hausmärchen der Brüder Grimm 3. Leipzig: Dieterich'sche Verlagsbuchhandlung. 


\section{Christine Shojaei Kawan}

Bottigheimer, Ruth B. 1996. Luftschlösser (AaTh 1430, 1681*). Rolf Wilhelm Brednich et al. (toim). Enzyklopädie des Märchens: Handwörterbuch zur historischen und vergleichenden Erzählforschung 8 (Klerus - Maggio). Berlin \& New York: de Gruyter, lk 1260-1265.

Brix, Hans 1907. H. C. Andersen og hans eventyr. København: Schubotheske Forlag.

Camarena Laucirica, Julio \& Chevalier, Maxime 1995. Catálogo tipológico del cuento folklórico español: Cuentos maravillosos. Biblioteca románica hispánica IV. Textos 24. Madrid: Gredos.

Christensen, Arthur 1936. La princesse sur la feuille de myrte et la princesse sur le pois. Acta Orientalia 14, lk 241-257.

Christensen, Georg 1960. H. C. Andersen og de danske folkeeventyr II: Kilderne for de enkelte eventyr. Danske Studier 4, lk 161-174.

Davidson, James N. (toim) 1998. Courtesans \& Fishcakes: the Consuming Passions of Classical Athens. New York: St. Martin's Press. (Et raamat ei olnud mulle kättesaadav, osundasin sellele New York Times'i Interneti-portaali vahendusel (http://www.nytimes.com/pages/books - 10. september 2003)).

Dowling, Patrick John 1935. The Hedge Schools of Ireland. Dublin \& Cork: Talbot Press.

Ellis, Georg 1848. Specimens of early English metrical romances: To which is prefixed an historical introduction on the rise and progress of romantic composition in France and England. London: Henry G. Bohn.

Eventyr $1963=H$. C. Andersens Eventyr I: 1835-42. Kritisk udgivet efter de originale Eventyrhæfter med Varianter ved Erik Dal og Kommentar ved Erling Nielsen. København: Hans Reitzels Forlag.

Evertyr $1964=$ H. C. Andersens Eventyr II: 1843-55. Kritisk udgivet efter de originale Eventyrhæfter med Varianter ved Erik Dal og Kommentar ved Erling Nielsen. København: Hans Reitzels Forlag.

Eventyr $1965=$ H. C. Andersens Eventyr III. 1856-65. Kritisk udgivet efter de originale Eventyrhæfter med Varianter ved Erik Dal og Kommentar ved Erling Nielsen. København: Hans Reitzels Forlag.

Eventyr $1966=$ H. C. Andersens Eventyr IV: 1861-66. Kritisk udgivet efter de originale Eventyrhæfter med Varianter ved Erik Dal og Kommentar ved Erling Nielsen. København: Hans Reitzels Forlag.

Eventyr 1990a = H. C. Andersens Eventyr VI. Kritisk udgivet efter de originale Eventyrhæfter med Varianter ved Erik Dal og Kommentar ved Erling Nielsen. Udgivet under medvirken af Flemming Hovmann. København: Hans Reitzels Forlag. 


\section{Christine Shojaei Kawan}

Eventyr $1990 \mathrm{~b}=$ H.C. Andersens Eventyr VII. Kritisk udgivet efter de originale Eventyrhæfter med Varianter ved Erik Dal og Kommentar ved Erling Nielsen. Efter forarbejder af Erling Nielsen udarbejdet af Flemming Hovmann. København: Hans Reitzels Forlag.

Fischer, Hermann \& Bolte, Johannes (toim) 1895. Die Reise der Söhne Giaffers aus dem Italienischen des Christoforo Armeno übersetzt durch Johann Wetzel 1583. Bibliothek des litterarischen Vereins in Stuttgart 208. Tübingen: Litterarisches Verein.

Gaudes, Rüdiger 1987. Kambodschanische Volksmärchen. Berlin: Akademie.

Glyn, Jones W. 1993. Andersen in English - A Feasability Study II. Johan de Mylius et al. (toim). Andersen og verden: Indlæg fra den Første Internationale H. C. Andersen-Konference 25.-31. august $1991=$ Andersen and the world: Papers from the First International Hans Christian Andersen Conference; 25 to 31 August 1991. Odense: Odense Universitetsforl., lk $210-216$.

Goldberg, Christine 1997. The Tale of the Three Oranges. Folklore Fellows' Communcations 117: 263. Helsinki: Suomalainen Tiedeakatemia.

González Sanz, Carlos 1996. Catálogo tipológico de cuentos folklóricos aragoneses. Artularios 1. Zaragoza: Instituto Aragones de Antropologia.

Gonzenbach, Laura 1870. Sicilianische Märchen aus dem Volksmund gesammelt 1-2. Leipzig: W. Engelmann

Graeber, Wilhelm 2000. Ouville, Antoine Le Métel sieur d'. Rolf Wilhelm Brednich et al. (toim). Enzyklopädie des Märchens: Handwörterbuch zur historischen und vergleichenden Erzählforschung 10: (Nibelungenlied - Prozessmotive). Berlin \& New York: de Gruyter, lk 454-458.

Grimm 1843a = Grimm, Jacob \& Grimm, Wilhelm. Kinder und Hausmärchen 1. Grosse Ausgabe. 5., täiend. tr. Göttingen: Dieterich.

Grimm 1843b = Grimm, Jacob \& Grimm, Wilhelm. Kinder und Hausmärchen 2. Grosse Ausgabe. 5., täiend. tr. Göttingen: Dieterich.

Grimm $1980=$ Grimm, Jacob \& Grimm, Wilhelm. Kinder- und Hausmär chen 2. Mit den Originalanmerkungen der Brüder Grimm. Toim Heinz Rölleke. Stuttgart: Reclam.

Grimm 1984 = Grimm, Jacob \& Grimm, Wilhelm. Kinder- und Hausmärchen 3. Mit den Originalanmerkungen der Brüder Grimm. Toim Heinz Rölleke. Stuttgart: Reclam.

Grimmid $2000=$ Grimm, Jacob \& Grimm, Wilhelm. Vendade Grimmide muinasjutud. Tallinn: Ersen.

Haboucha, Reginetta 1992. Types and Motifs of the Judeo-Spanish Folktales. Garland reference library of the humanities 1397. New York \& London: Garland. 


\section{Christine Shojaei Kawan}

Hasan-Rokem, Galit 2000. Web of Life: Folklore and Midrash in Rabbinic Literature. Contraversions. Stanford (California): Stanford University Press.

Hatami, Mahroo 1977. Untersuchungen zum persischen Papageienbuch des Nahšabi. Islamkundliche Untersuchungen 47. Freiburg: K. Schwarz.

Hertel, Johannes (tõlk) 1920. Kathāratnākara: Das Märchenmeer: Eine Sammlung indischer Erzählungen von Hēmavijaya Gan̄̄ 2. München: Georg Müller.

Hill, Shaun \& Wilkins, John 1996. Mithaikos and Other Greek Cooks. Harlan Walker (toim). Cooks \& Other People: Proceedings of the Oxford Symposium on Food and Cookery 1995. Devon: Prospect Books, lk 144-148.

Hodne, Ørnulf 1984. The Types of the Norwegian Folktale. Instituttet for sammenlignende kulturforskning B: 68. Oslo: Universitetsforlaget \& London: Global. distributor.

Hoffmann Helmut 1992. Vetālapancavimśatikā. Walter Jens (toim). Kindlers Neues Literatur Lexikon 19 (Anonyma: Kollektivwerke, Stoffe: La Zz). München: Kindler.

Holbek, Bengt 1977. Andersen, Hans Christian. Kurt Ranke et al. (toim). Enzyklopädie des Märchens: Handwörterbuch zur historischen und vergleichenden Erzählforschung 1 (Aarne - Bayerischer Hiasl). Berlin \& New York: de Gruyter, lk 490-493.

Holbek, Bengt 1990. Hans Christian Andersen's Use of Folktales. Morten Nøjgaard et al. (toim). The Telling of Stories: Proceedings of the Thirteenth International Symposium organized by the Centre for the Study of Vernacular Literature in the Middle Ages held at Odense University on 21-22 November, 1988. Odense: Odense University Press, lk 165-177.

Hyltén-Cavallius, Gunnar Olof \& Stephens, George 1844. Svenska Folksagor och Äfventyr 1. Stockholm: Bohlin.

Imbriani, Vittorio (koost) 1877. La novellaja fiorentina: Fiabe e novelline stenografate in Firenze dal dettato popolare. Livorno: Vigo.

Jason, Heda 1964-1965. Types of Jewish-Oriental Oral Tales. Fabula 7, lk 115-224.

Jason, Heda 1989. Types of Indic Oral Tales. Folklore Fellows' Communications 242. Helsinki: Suomalainen Tiedeakatemia.

Jung, Christiane 1994. Vanad head muinasjutud. Tallinn: Kirilille Kirjastus.

Jung, Christiane 2000. Vanad head muinasjutud. Tallinn: Kirilille Kirjastus.

Jurkschat, Christoph = Jurkšaitis, Kristupas 1898. Litauische Märchen und Erzählungen:Aus dem Volke gesammelt und in verschiedenen Dialekten, vornehmlich aber im Galbraster Dialekt. Heidelberg: Winter. 
Keller, Adelbert (toim) 1841. Dyocletianus Leben von Hans von Bühel. Bibliothek der gesammten deutschen National-Literatur von der ältesten bis auf die neuere Zeit 22. Quedlinburg \& Leipzig: Basse.

Kerbelyte, Bronislava 1999. Lietuviu pasakojamosios tautosakos katalogas 1 = The Catalogue of Lithuanian Narrative Folklore. Vilnius: Lietuviu literaturos ir tautosakos institutas.

Kvideland, Reimund \& Sehmsdorf, Henning K. (toim). 1999. All the World's Reward: Folktales Told by Five Scandinavian Storytellers. Seattle \& London: University of Washington Press.

Köhler-Zülch, Ines 1993. Katzenschloß (AT 545A). Rolf Wilhelm Brednich et al. Enzyklopädie des Märchens: Handwörterbuch zur historischen und vergleichenden Erzählforschung 7 (Ibn al-Gauzi - Kleines Volk). Berlin \& New York: de Gruyter, lk 1126-1131.

Köhler-Zülch, Ines 1999. Der Diskurs über den Ton. Zur Präsentation von Märchen und Sagen in Sammlungen des 19. Jahrhunderts. Christoph Schmitt (koost). Homo narrans: Studien zur populären Erzählkultur. Festschrift für Siegfried Neumann zum 65. Geburtstag. Rostocker Beiträge zur Volkskunde und Kulturgeschichte 1. Münster: Waxmann, lk 25-50.

Köhler-Zülch, Ines \& Shojaei Kawan, Christine 1990. Les fréres Grimm et leurs contemporains: Quelques réflexions sur l'adaptation des contes traditionnels dans le contexte socio-culturel du XIXe siécle. Veronika GörögKarady \& Michéle Chiche (toim). D'un conte [---] à l'autre: La variabilité dans la littérature orale $=$ From one tale [---] to the other: Variability in oral literature. Paris: Éditions du CRNS, lk 250-260.

Larrea Palacín, Arcadio de 1952. Cuentos populares de les judios del norte de Marruecos I. Tetuán 55. Madrid: Consejo Superior de Investigaciones Científicas.

Le Métel d'Ouville, Antoine 1883. L'Élite des contes: Réimprimée sur l'édition de Rouen 1680 avec une préface et des notes. Paris: Librairie des Bibliophiles.

Liungman, Waldemar 1961. Die schwedischen Volksmärchen: Herkunft und Geschichte. Veröffentlichungen des Instituts für Deutsche Volkskunde 20. Berlin: Akademie-Verlag.

Loiseleur-Deslongchamps, Auguste Louis Armand 1838. Essai sur les fables indiennes et sur leur introduction en Europe [---]: Suivi du Roman des sept sages de Rome en prose. Paris: Robert.

Lorimer, David Lockhart Robertson 1935. The Burushaski Language 2. Instituttet for Sammenlignende Kulturforskning B: 29. Oslo: Instituttet for Sammilignende Kulturforskning.

Lundt, Bea 1999. Die "Prinzessin auf der Erbse" als Quelle historischer Sozialisationsforschung. Udo Arnold, Peter Meyers, Uta C. Schmidt (toim). 


\section{Christine Shojaei Kawan}

Stationen einer Hochschullaufbahn: Festschrift für Annette Kuhn zum 65. Geburtstag. Dortmund: Ebersbach, lk 247-260.

Lörincz, László 1979. Mongolische Märchentypen. Asiatische Forschungen 61. Wiesbaden: Harrassowitz.

Marzolph, Ulrich 1979. Die Vierzig Papageien: Cehel Tuti das persische Volksbuch: Ein Beitrag zur Geschichte des Papageienbuches. Beiträge zur Sprach- und Kulturgeschichte des Orients 29. Walldorf: Verlag für Orientkunde.

Marzolph, Ulrich 1999. Nez.āmi. Rolf Wilhelm Brednich et al. (toim). Enzyklopädie des Märchens: Handwörterbuch zur historischen und vergleichenden Erzählforschung 9 (Magica-Literatur - Nezami). Berlin \& New York: de Gruyter, lk 1434-1440.

Marzolph, Ulrich 2002a. Orientalisches Erzählgut in Europa. Rolf Wilhelm Brednich et al. (toim). Enzyklopädie des Märchens: Handwörterbuch zur historischen und vergleichenden Erzählforschung 10 (Nibelungenlied Prozessmotive). Berlin \& New York; de Gruyter, lk 362-373.

Marzolph, Ulrich 2002b. Papageienbuch. Rolf Wilhelm Brednich et al. (koost). Enzyklopädie des Märchens: Handwörterbuch zur historischen und vergleichenden Erzählforschung 10 (Nibelungenlied - Prozessmotive). Berlin \& New York: de Gruyter, lk 526-531.

Messac, Régis 1929. Le "Detective Novel" et l'influence de la pensée scientifique. Bibliothéque de la Revue de littérature comparée 59. Paris: Honoré Champion. (Uustrükk: Genóve: Slatkine Reprints 1975.)

Minajev 1876-1877 = Минаев, Иван. Индийские сказки и легенды, собранные в Камаоне в 1875 году. Записки Историко-филологического факультета Императорского С.-Петербургского университета 2. (Tsiteeritud Josef Schicki (1934: 136-141) järgi.)

Misrahi, Jean (toim) 1933. Le Roman des sept sages. Paris: de l'éd Réimpr. Moser-Rath, Elfriede 1979. Brautproben. Kurt Ranke et al. (toim). Enzyklopädie des Märchens: Handwörterbuch zur historischen und vergleichenden Erzählforschung 2 (Bearbeitung - Christusbild). Berlin \& New York: de Gruyter, lk 745-753.

Murch, Alma Elizabeth 1958. The Development of the Detective Novel. London: Peter Owen.

Mäll, Linnart \& Masing, Uku 1969. Vetāla kakskümmend viis juttu. Tallinn: Eesti Raamat.

Nielsen, Erling: Hans Christian Andersen, mit Selbstzeugnissen und Bilddokumenten. Hamburg 1995. 
Oesterley, Hermann (toim) 1873. Baitál Pachísí oder die 25 Erzählungen eines Dämon: In deutscher Bearbeitung mit Einleitung, Anmerkungen und Nachweisen. Bibliothek orientalischer Märchen und Erzählungen in deutscher Bearbeitung 1. Leipzig.

Oì Súilleabháin, Sean \& Christiansen, Reidar Thoralf 1967. The Types of the Irish Folktale. Folklore Fellows' Communications 188. Helsinki: Suomalainen Tiedeakatemia.

Ottendorff-Simrock Walther 1966 (toim). Die Grimms und die Simrocks in Briefen: 1830 bis 1864. Bonn: Ferdinand Dümmler.

Paulys Real-Encyklopädie der klassischen Altertumswissenschaft 1931-. Stuttgart: Druckenmüller.

Pedersen, Viggo Hjørnager 1993. A Wonderful Story of a True Soldier and a Real Princess. Problems in Connection with the Rendition of Hans Andersen's Vocabulary in English. Johan de Mylius et al. (toim). Andersen og verden: Indlæg fra den Første Internationale H. C. Andersen-Konference 25.31. august $1991=$ Andersen and the world: Papers from the First International Hans Christian Andersen Conference; 25 to 31 August 1991. Odense: Odense Universitetsforl., lk 197-209.

Penzer, Norman Mosley (toim) 1923 = Somadeva. The ocean of story: Being C. H. Tawney's translation of Somadeva's Kathāsaritsāgara (or ocean of streams of story) [---] 6. Delhi \& Varanasi \& Patna: Motiral Banarsidass.

Piemontese, Angelo Michele 1995. Gli “Otto Paradisi” di Amir Khusrau da Delhi. Una lezione persiana del "Libro di Sindbad" fonte del "Peregrinaggio" di Cristoforo Armeno. Atti della Accademia Nazionale dei Lincei 392. Memoire / Classe di scienze morali, storiche e filologiche 9: 6: 3. Rome: Accademia Naz. dei Lincei, lk 317-418.

Polo de Beaulieu, Marie-Anne (toim) 1991. La Scala Coeli de Jean Gobi. Sources d'histoire médiévale. Paris: CNRS, lk 377-391.

Rajna, Pio (toim) 1880. Storia di Stefano figliuolo d'un imperatore di Roma: Versione in ottava rima del Libro dei Sette Savi. Bologna: Romagnoli.

Ranke, Kurt 1979. Brüder: Die scharfsinnigen B. (AT 655, 655A). Kurt Ranke et al. (toim). Enzyklopädie des Märchens: Handwörterbuch zur historischen und vergleichenden Erzählforschung 2 (Bearbeitung - Christusbild). Berlin \& New York: de Gruyter, lk 874-887.

Ranke, Kurt \& Schenda, Rudolf 1979. Christoforo Armeno. Kurt Ranke et al. (toim). Enzyklopädie des Märchens: Handwörterbuch zur historischen und vergleichenden Erzählforschung 2 (Bearbeitung - Christusbild). Berlin \& New York: de Gruyter, lk 1400-1404. 


\section{Christine Shojaei Kawan}

Rausmaa, Pirkko-Liisa 1988 (toim). Suomalaiset kansansadut 1: Ihmesadut. Suomalaisen Kirjallisuuden Seuran Toimituksia 482. Helsinki. Suomalaisen Kirjallisuuden Seura.

Roberts, Warren Everett 1964. Norwegian folktale studies: Some aspects of distribution. Studia Norvegica 13. Scandinavian university books. Oslo \& Bergen: Universitetsforlaget.

Rosen, Georg [1923] (tõlk). Das Papageienbuch. Leipzig: Insel-Verlag.

Ruben, Walter 1964. Ozean der Märchenströme 1: Die 25 Erzählungen des Dämons (Vetalapancavimsati). Folklore Fellows' Communications 133. Helsinki: Suomalainen Tiedeakatemia.

Rölleke, Heinz 1988 (koost). Redensarten des Volks, auf die ich immer horche: Das Sprichwort in den Kinder- und Hausmärchen der Brüder Grimm. Bern et al.: Lang.

Scherf, Walter 1995. Das Märchenlexikon 2 (L-Z). München: Beck.

Schick, Josef 1934. Die Scharfsinnsproben 1: Der ferners Orient. Corpus Hamleticum 1. Sagengeschichtliche Untersuchungen 4. Leipzig: O. Harrassowitz.

Schick, Josef 1938. Die Scharfsinnsproben 2: Von Vorderasien bis Germanien. Corpus Hamleticum 1. Sagengeschichtliche Untersuchungen 5. Berlin: Felber.

Schier, Kurt (koost ja tõlk) 1971. Schwedische Volksmärchen. Die Märchen der Weltliteratur 2. Düsseldorf \& Köln: Diederichs.

Schmidt, Richard (tõlk) 1897. Die Marāthī-Uebersetzung der Sukasaptati. Abhandlungen für die Kunde des Morgenlandes 10: 4. Leipzig: Brockhaus [in Komm.].

Schmidt, Richard (tõlk) 1899. Die Sukasaptati (Textus ornatior). Stuttgart: Kohlhammer.

Schneller, Christian 1867. Nr. 45: Die Empfindlichste. Märchen und Sagen aus Wälschtirol: Ein Beitrag zur deutschen Sagenkunde. Innsbruck: Verlag der Wagner'schen Universitäts-Buchhandlung, lk 128-129.

Schoenfeld, Elisheva 1990. Handlung: Die vornehmste H (AT 976). Rolf Wilhelm Brednich et al. (toim). Enzyklopädie des Märchens: Handwörterbuch zur historischen und vergleichenden Erzählforschung 6 (Gott und Teufel auf Wanderschaft - Hyltén-Cavallius). Berlin \& New York: de Gruyter, lk 459-464.

Shojaei Kawan, Christine 1996. Kriminalroman. Rolf Wilhelm Brednich et al. (toim). Enzyklopädie des Märchens: Handwörterbuch zur historischen und vergleichenden Erzählforschung 8 (Klerus - Maggio). Berlin \& New York: de Gruyter, lk 440-460. 


\section{Christine Shojaei Kawan}

Shojaei Kawan, Christine 2000. Orangen: Die drei O. (AT 408). Rolf Wilhelm Brednich et al. (toim). Enzyklopädie des Märchens: Handwörterbuch zur historischen und vergleichenden Erzählforschung 10 (NibelungenliedProzessmotive ). Berlin \& New York: de Gruyter, lk 346-355.

Simonsuuri, Lauri \& Rausmaa, Pirkko-Liisa (koost) 1968. Finnische Volkserzählungen. Fabula Supplement-Serie A: 7. Berlin: de Gruyter.

Tawney, Charles Henry (tõlk) 1884 = Somadeva. Kathi Sarit Sigara or Ocean of the Streams of Story 2. Calcutta: Baptist Mission Press.

Teder, Eerik 1996. Hans Christian Andersen ja Eesti. Andersen, Hans Christian. Lumikelluke: Muinasjutud ja lood. Tallinn: Eesti Raamat, lk 510-517.

Thompson, Stith 1956. Motif-index of folk-literature: A classification of narrative elements in folktales, ballads, myths, fables, mediaeval romances, exempla, fabliaux, jest-books and local legends $3(\mathrm{~F}-\mathrm{H})$. København: Rosenkilde \& Bagger.

Thompson, Stith \& Balys, Jonas 1958. The Oral Tales of India. Indiana University Publications. Folklore Series 10. Bloomington: Indiana University Press.

Ting, Nai-tung 1978. A type index of Chinese folktales: In the oral tradition and major works of non-religious classical literature. Folklore Fellows' Communications 223. Helsinki: Suomalainen Tiedeakatemia.

Topsøe-Jensen, Helge \& Bom, Kaj \& Bøgh, Knud (toim) 1945. H. C. Andersens brevveksling med Jonas Collin den ældre og andre medlemmer af det Collinske hus 1. København: Munksgaard.

Uhle, Heinrich (tõlk) 1924 = Somadeva. Vetalapantschavinsati. Die 25 Erzählungen eines Dämons. Meisterwerke orientalischer Literaturen 9. München: Müller.

Uther, Hans-Jörg 1993. H. C. Andersen und Deutschland:Zur frühen Rezeption seiner Märchen. Johan de Mylius et al. (toim). Andersen og verden: Indleg fra den Første Internationale H. C. Andersen-Konference 25.-31. august 1991 = Andersen and the world: Papers from the First International Hans Christian Andersen Conference; 25 to 31 August 1991. Odense: Odense Universitetsforl., lk 367-375.

Vries, Jan de 1928. Volksverhalen uit Oost-Indie (Sprookies en fabels) 2.Zutphen.

Wölcken, Fritz 1953. Der lierarische Mord: Eine Untersuchung über die englische und amerikanische Detektivliteratur. Nürnberg: Nest. 